IZA DP No. 10176

Who Trusts Others? Community and Individual Determinants of Social Capital in a Low Income Country

M. Niaz Asadullah

August 2016 


\title{
Who Trusts Others? Community and Individual Determinants of Social Capital in a Low Income Country
}

\author{
M. Niaz Asadullah \\ University of Malaya, University of Reading, IZA, \\ SKOPE, University of Oxford and SEED, University of Manchester
}

Discussion Paper No. 10176

August 2016

IZA

P.O. Box 7240

53072 Bonn

Germany

Phone: $+49-228-3894-0$

Fax: +49-228-3894-180

E-mail: iza@iza.org

\begin{abstract}
Any opinions expressed here are those of the author(s) and not those of IZA. Research published in this series may include views on policy, but the institute itself takes no institutional policy positions. The IZA research network is committed to the IZA Guiding Principles of Research Integrity.

The Institute for the Study of Labor (IZA) in Bonn is a local and virtual international research center and a place of communication between science, politics and business. IZA is an independent nonprofit organization supported by Deutsche Post Foundation. The center is associated with the University of Bonn and offers a stimulating research environment through its international network, workshops and conferences, data service, project support, research visits and doctoral program. IZA engages in (i) original and internationally competitive research in all fields of labor economics, (ii) development of policy concepts, and (iii) dissemination of research results and concepts to the interested public.
\end{abstract}

IZA Discussion Papers often represent preliminary work and are circulated to encourage discussion. Citation of such a paper should account for its provisional character. A revised version may be available directly from the author. 


\section{ABSTRACT \\ Who Trusts Others? Community and Individual Determinants of Social Capital in a Low Income Country*}

This study presents new evidence on individual and community-specific determinants of social trust using data from 96 villages in Bangladesh. We find perceived institutional trust to be positively correlated with stated inter-personal trust. At the same time, there is significant social distance among various faith groups in our data: both Hindus and Muslims trust their coreligionists more than they trust those from other religions. Hindus in districts bordering India trust non-Hindus significantly less, compared to those in interior regions, which suggests that the results do not simply capture the effect of minority/majority status. Trust towards non-Muslims is negatively correlated with Islamic school attendance among Muslim respondents, while religiosity tends not to play any role. Compared to religion, the effects of institutional trust and local economic development are modest. These findings are robust to control for a range of individual- and community-level correlates, and enumerator fixedeffects.

JEL Classification: $\quad$ O12, Z1

Keywords: Bangladesh, Hindu, institutions, religion, trust

Corresponding author:

M. Niaz Asadullah

Centre for Poverty and Development Studies (CPDS)

Faculty of Economics and Administration

University of Malaya

Kuala Lumpur 50603

Malaysia

E-mail: m.niaz@um.edu.my

\footnotetext{
* I gratefully acknowledge institutional support from the World Bank, the Institute for Governance Studies (IGS) of BRAC University and the Research and Evaluation Division (RED) of BRAC. The paper was written while I was in receipt of a Leverhulme Trust research fellowship (from September 2011 to December 2012) on the rise of Islamic schools in Bangladesh. An earlier version of the paper was presented in a research seminar at Monash University, Malaysia. The usual disclaimers apply.
} 


\section{NON-TECHNICAL SUMMARY}

Social trust, the confidence people have that strangers on whom they have no specific information about will not take advantage of them, is considered to facilitate long-term growth, democratic stability and subjective well-being. Trust is particularly important in the rural areas of developing countries where formal markets are often under-developed, and the majority of economic transactions take place in the informal sector. Some scholars have argued that the level of trust is determined by schooling and institution quality while others contest that the extent to which one trusts others may depend on factors such as religious affiliation, and/or degree of religiosity. Faith orientation of the school can be also important. Youths may be exposed to schools that limit interaction with other faith groups and operate in segmented communities with limited media access. If so, social capital in Muslim countries such as Malaysia, India, Pakistan, Indonesia and Nigeria can be undermined by religious/ethnic diversity among their populations, faith-specific schooling and poor governance. Faith identity is a contentious topic in South Asia where countries are greatly segmented along religious lines. Media reports on communal riots causing deaths and damages to properties in the region are quite frequent. There is a steep rise in religious violence and segregation in India and Bangladesh.

This raises an important question: how can public policy foster trust in socially diverse communities?

We answer this question in the context of Bangladesh, a country well-known for various forms of governance crises, poor quality of public institutions, low level of schooling and the presence of a number of religious minority groups. Hindus for instance account for about a tenth of Bangladesh's total population. Therefore we study the trust attitude between Muslims and Hindus.

The measurement of trust is a contentious topic in the social science literature. Therefore, in addition to using the generalized trust question, we have employed questions to directly capture trust towards specific social groups. In particular, we combine individual and aggregate (i.e. community) level variables to explain inter-personal trust among 2400 household-heads across 96 villages in Bangladesh. The survey was conducted in 12 districts during 2007-2008. We use survey responses to a range of questions relating to in-group and out-group trust as dependent variables, and estimate multivariate models focusing on a number of correlates -- religious affiliation, institutional trust and religious schooling of individuals, as well as the level of economic development in the village.

Two key questions examined are:

(i) Is the "religion effect" significant and specific to certain religious groups and geographic locations?

(ii) How does the effect of community attributes (e.g. religious composition and the level of economic development of the village), perceived institutional trust and Islamic education compare with that of religion?

We find significant social distance among various faith groups in the data: both Hindus and Muslims trust their coreligionists more than they trust those from other religions. Religious minorities such as Hindus trust Muslims more than Muslims trust Hindus. We also find no evidence that Hindus are distrustful of the wider society in general. If anything, they trust nonMuslims of all denominations and NGO workers more compared to Muslims. When compared to religion, effects of institutional trust and local economic development (including presence of NGO activity) are modest. 
These findings do not proxy for between religion differences in institutional trust. This is despite the fact that perceived institutional trust increases inter-personal trust in our data. These findings are neither driven by religious identities of the interviews. We do not find that the inter-group trust attitude of individuals is owing to minority/ majority status based on religion. This is because Hindus trust other Hindus and Muslims less in locations bordering Hindu majority India compared to interior regions. However, the lack of trust towards Hindus (and other non-Muslims) is significantly correlated with Islamic school (i.e. madrasa) attendance amongst Muslim respondents whilst religiosity appears to play no role.

The above findings highlight new challenges for Muslim-majority Bangladesh where in recent years there is growing violence against the country's minority populations.

The between-group trust deficit documented in our study could be shaped by the theology of respective religious groups. According to our findings, however, the role of religion in inculcating a trusting attitude is ambiguous. We do not find a direct role of religious observance among Muslims on trust attitudes. This is not unsurprising because all major faiths, including Islam emphasize equality, peace, community service, and responsibilities towards the poor and vulnerable, including strangers.

The Hindu-Muslim differences in trust attitude that we have documented can be driven by the actual experience of people rather than the theology of the particular religions. In recent years, there are growing signs of religious intolerance around the world. In Bangladesh, Hindu priests and teacher have been murdered along with incidents of attacks on Hindu devotees at the temple. Several dozen houses and idols belonging to Hindus have been vandalized. There have also been several other attacks on members of other faith communities which also saw attacks on the places of worship of Shias, Christians, and the Buddhists. Events such as these would undermine between-group solidarity and create mistrust between Bangladesh's two main religious communities, Muslims and Hindus, limiting the scope for creating social capital in the long-run.

It is also possible that existing mistrust towards minorities may be fueling recent communal violence. In this context, improvements in the rule of law and institutional provisions protecting minority rights and livelihoods will be critical to rebuild social trust. In addition, we have highlighted two policy channels for fostering inter-personal trust.

First, the significant association between institutional trust and social trust suggests that policy reforms that reduce corruption may improve interpersonal-trust via increasing institutional trust in rural Bangladesh. Here policy measures against corruption such as social campaigns using the media and school curriculum reform to instill moral values can be effective. Second, while we found no effect of years of schooling, madrasa attendance was negatively correlated with level of trust towards minority religious groups. If this effect is causal, this suggests that social trust can be fostered through appropriate educational reform programs. Curriculum reform targeting Islamic schools can improve generalized trust attitude among one segment of the Muslim population in Bangladesh. Indeed evidence indicates that madrasa students using state approved curriculum show favorable trust attitudes compared to their peers from unregulated non-state madrasas.

Overall, our study thus lends some support to the view that social trust in low income countries can be built through a combination of institutional and education policy reforms. 


\section{Introduction}

Trust among members of a society is considered to facilitate long-term growth, democratic stability and subjective well-being (Zak and Knack, 2001; Bjørnskov, 2003; Beugelsdijk, 2006; Tabellini, 2010; Dearmon and Grier, 2009; Algan and Cahuc, 2010). Social trust, the confidence people have that strangers on whom they have no specific information about will not take advantage of them, is particularly important in the rural areas of developing countries where formal markets are often under-developed, and the majority of economic transactions take place in the informal sector (Schneider and Enste, 2000; Tu and Bulte, 2010; D’Hernoncourt and Méon, 2012). Yet the level of social trust varies substantially across countries and is especially low in developing countries (Ahmed and Salas, 2009). This raises an important question: can public policy foster trust? According to some researchers (e.g. Narayan 2002; Knack and Zak, 2003; Dixit, 2004; Rothstein, 2005; Bidner and Francois, 2011), the answer is affirmative, since the level of trust appears to be partly determined by schooling and institution quality. At the same time, the extent to which one trusts others may depend on factors such as religious affiliation, and/or degree of religiosity (Tan and Vogel, 2008; Ahmed 2009; Johansson-Stenman et al., 2009; Berggren and Bjørnskov, 2011; Sarkissian, 2012; Chuah, Fahoum and Hoffmann, 2013). In general, there is an emerging consensus that levels of trust are shaped by individual specific attributes, as well as aggregate factors such as local institutions and community characteristics (Wang and Gordon, 2011).

More systematic documentation of the determinants of trust in varying institutional and demographic contexts can aid in understanding the deeper determinants of inter-personal trust around the world. In this connection, Bangladesh is an interesting case study. The country is well-known for various forms of 
governance crises (Chaudhury et al., 2006; Asadullah, Savoia, and Mahmud, 2014), and poor quality of public institutions, which are thought to undermine social trust (Knox 2009). Large scale provision of social services through NGOs partly makes up for poor governance in the social sector, and fosters trust in rural areas (Kabeer and Matin, 2005). This suggests that public policies can aid the process of social capital formation in rural developing countries. This is also true if it is found that the lack of inter-personal trust is driven by community level factors such as economic inequality and level of economic development of a village.

On the other hand, social trust can be undermined by religious composition and low level of schooling of the population. Non-Muslims (Hindus) account for little over 10\% (8\%) of the population in Bangladesh. All major faiths, including Islam, have doctrinal commitments to equality, peace, community service, and responsibilities towards the poor and vulnerable, including strangers, which can contribute to the development of trusting relationships within the society (Neusner and Chilton, 2005). At the same time, Muslims may be exposed to institutional environments (e.g. Islamic schools) that limit interaction with other faith groups. ${ }^{1}$ This may create distrust between Muslims and non-Muslims although at the same time increasing trust towards other Muslims. Although some of these issues have been studied in cross-country studies using survey based (e.g. Alessina and La Ferrara 2002; Bjørnskov, 2007; Daniels and von der Ruhr, 2010) and/or experimental measures (Cardenas and Carpenter, 2008) of trust, research using country-specific large survey data that combines an analysis of spatial, religious and demographic determinants of trust is limited for developing countries.

\footnotetext{
${ }^{1} \mathrm{~A}$ similar social setting is also observed in ultra-Orthodox populations in Israel where youths grow up in segmented communities with limited media access (Berman 2000).
} 
Our paper builds on the existing cross- and within- country studies, and contributes to the limited developing country literature on social trust using a novel household survey dataset from Bangladesh, a poor country with significant religious minority populations and "governance deficit”. In particular, we combine individual and aggregate (i.e. community) level variables to explain inter-personal trust among household-heads across 96 villages in the country. We use survey responses to a range of questions relating to in-group and out-group trust as dependent variables, and estimate regression models focusing on a number of correlates: religious affiliation, institutional trust and religious schooling of individuals, as well as the level of economic development in the village. The key questions examined are: (a) Is the “religion effect” significant and specific to certain religious groups and geographic locations? (b) How does the effect of community attributes (e.g. religious composition and the level of economic development of the village), perceived institutional trust and Islamic education compare with that of religion? To the best of our knowledge, this is the first within-country study on the general determinants of inter-personal trust in South Asia that employs a nationally spread out survey data set. ${ }^{2}$

The remainder of the paper is organized as follows. Section 2 discusses studies on social trust using developing country data. Section 3 discusses the sample and also explains our survey measure of trust. Section 4 presents the main results. Section 5 concludes.

\section{Study background}

\subsection{What we know about the determinants of inter-personal trust}

Social trust is viewed by many as a form of social capital. It plays an important role in economic and social transactions. Numerous studies have used country average of the

\footnotetext{
${ }^{2}$ None of the existing studies on South Asian countries employs a data set that examines the role of geography and community characteristics along with demographic factors (e.g. see Ahmed, 2009; Ahmed and Salas, 2009; Johansson-Stenman et al., 2009; Chuah, Fahoum, and Hoffmann, 2013).
} 
answers to the World Values Survey (WVS) question "In general, do you think that most people can be trusted....?” to measure social capital and document its impact on economic development. Studies confirm that the level of trust significantly differs among countries (Zak and Knack 2001; Ahmed and Salas, 2009). In most cases, the evidence is supportive of the view that the propensity of people within a country to trust each other is significantly related with various macroeconomic outcomes, governance, bureaucratic corruption and schooling level attained. However, Özcan and Bjørnskov (2011) find that social trust facilitates faster human development, but the impact occurs mainly in less democratic countries. Moreover, Horváth (2013) using data for nearly fifty countries, reveals that trust is key to economic growth in countries with a weak rule of law. These two studies thus highlight the importance of trust in a developing country setting where democracy and rule of law is lacking.

There are a number of theoretical explanations for cross-country variation in social trust. Some emphasizes behavioral sources of trustworthiness as a combination of well-functioning enforcement of contracts and cultural transmission of values of cooperation (e.g. Guiso, Sapienza and Zingales 2008; Tabellini, 2008). Others point out that institutions improve societal trust by detecting, checking and punishing opportunistic behaviour (e.g. Dixit, 2004). If true, formal institutions facilitate trust through establishing the rule of law, equitable access to justice, and a police force that protects citizens, while informal (e.g. religious) institutions regulate trust through social mechanisms (e.g. ostracism/shame to those who violate the norms; Narayan, 2002). However, formal institutions may also have the opposite effect by reducing the marginal returns to being trustworthy and in turn crowding out trust and trustworthiness (Aghion et al. 2010). While institutions increase the cost of betrayal enhancing people's willingness to trust, they may also decrease intrinsically motivated 
trust (Bohnet and Baytelman (2007). Irrespective of the debate on whether the actual effect of institution on trust is negative or positive, there is also a debate over whether social trust has institutional foundations. Some researchers are sceptical that social and political institutions can lead to high societal trust (Uslaner, 2002). In his critique of Beugelsdijk (2006), Uslaner (2008a) argues that generalized trust may not be a simple proxy for effective government and institutional quality; instead it can be seen as a moral value acquired early in life and hence resistant to bad experiences in later life. Moreover, low level of societal trust may lead to corrupt governments which in turn further lower inter-personal trust (Uslaner, 2008b). ${ }^{3}$

Empirical studies that employ pooled cross-section surveys such as the World Values Survey data have the advantage of exploring person-specific determinants of trust. A number of such studies explored the effect of religious observance and/or affiliation on trust in others. However, the evidence is mixed. Some report a positive effect of religion on trust (Tan and Vogel, 2008). For the US, Welch, Sikkink and Loveland (2007) find that Catholics and members of other denominations exhibit significantly less trust in strangers than in Protestants. Brañas-Garza et al. (2009) find for Latin America that trust toward others is positively linked with both religious observance and Catholic affiliation. Alesina and La Ferrara (2002) find that religious beliefs and ethnic origins do not significantly affect trust in the US. Similarly, Anderson, Mellor and Milyo (2010) find religious affiliation and participation not to be strongly associated with increased cooperation and trust in field experiments. In a more recent study, behaviour in the trust game is found to be unaffected by religionrelated variables (Brañas-Garza, Espín, and Neuman, 2013).

\footnotetext{
${ }^{3}$ See Uslaner (2013) for alternative views on the relationship between political/social institutions and inter-personal trust and Bachmann and Inkpen (2011) for a review of various strands of the literature on the role of institutions in the development of trust.
} 
At the same time, others report negative effects. For instance, Guiso, Sapienza, and Zingales (2003) find that religious people tend to be more racist. Berggren and Bjørnskov (2011) report a negative and significant relationship between religiosity (measured in terms of "importance of religion in day-to-day life") and trust in crosscountry data. Using the General Social Survey (GSS) data Daniels and von der Ruhr (2010) find that black Protestants, fundamentalist Protestants, and Catholics trust others less than individuals who do not claim a preference for a particular denomination. In contrast, liberal Protestants trust others more. Similarly, JohanssonStenman, Mahmud, and Martinsson (2009) find that both Hindus and Muslims in Bangladesh trust others from their own religion more than they trust people from other religions. ${ }^{4}$

Although all major religions call for behaving well to others, religious groups may primarily trust people in their own groups and distrust others, as well as cause division in the broader population. On the other hand, religious minorities may demonstrate a low level of trust as a consequence of violence and discrimination. ${ }^{5}$ At the same time, the observed effects can be spurious if religious groups differ significantly in terms of endowment of non-religious factors that matter for trust. Therefore the role of religion in predicting the level of trusting attitude can be ambiguous.

Beyond religious affiliation and individual experiences (e.g. educational orientation), community characteristics also influence the degree in which people trust each other (Alesina and La Ferrara, 2002). Various studies confirm the role of legal

\footnotetext{
${ }^{4}$ There is also a large volume of studies that has carried out laboratory tests on how group membership (religious, social, residential) influence trust (e.g. see Güth et al 2008, Güth et al. 2009, Smith 2011, and Crepaz et al. 2014).

${ }^{5}$ See Alesina and La Ferrara (2002) for similar evidence for the US. Using US data they find that a recent history of traumatic experiences and belonging to a group that historically felt discriminated against are associated with low trust.
} 
and political institutions in determining the level of trust in the economy. For instance, Bidner and Francois (2011) use the World Values Survey data for a large number of countries and find that trust may be the result of well-functioning institutions of law enforcement and punishment. Lastly, irrespective of the underlying political and legal institutional regime, the level of trust can be adversely affected by the prevailing economic conditions (such as poverty, income and racial inequality) in the society (e.g. ; Rainer and Siedler, 2009; Bjørnskov, 2007; Alesina and La Ferrara (2002).

In sum, although cross-country studies (using country-level or pooled cross section data) and field experiments abound, for reasons related to data unavailability, research on social trust in developing countries remains limited. Apart from the studies cited above, we are not aware of other published developing country research regarding this question. ${ }^{6}$ More importantly, we know nothing about the role of perceived institutional quality, religious schooling and inequality in the community -none of the published developing country studies cited in this section focus on these factors. Studies using WVS data (e.g. Wang and Gordon, 2011) or the Gallup World Poll survey (e.g. Berggren and Bjørnskov, 2011) do include developing country respondents. However, WVS is not suitable for full-blown within-country analysis, since the sample is not sufficiently spread across local communities and/or contains no disaggregated community-level information.

\footnotetext{
${ }^{6}$ See Cardenas and Carpenter (2008), which reviews a few developing and middle income country studies on trust that use field experiments. Most of these studies employ a small sample, and are thus unable to explore the general determinants of trust (e.g. geographic and institutional correlates) in a country (e.g. see Holm and Danielson, 2005; Johansson-Stenman et al, 2009). One exception is the study by Haddad and Maluccio (2003) who examine inter-personal trust using household panel data from South Africa. However, the authors neither focus on religious membership, nor on institutions, as determinants of trust.
} 


\subsection{Why study social trust in Bangladesh}

For four reasons, Bangladesh provides a rich institutional context for investigating the determinants of social trust. First, trust may be undermined because of religious divide in the Bangladeshi population. Religious groups may exhibit out-group bias due to religious beliefs or this may simply reflect their relative status within the population (e.g. Hindus being the minority). ${ }^{7}$ Second, a significant proportion of Muslims are educated in 'madrasas' in Bangladesh. Given the emphasis on teachings of Islam, we can expect madrasa educated individuals to be more pro-social (Ahmed 2009; Delavande and Zafar, 2015). ${ }^{8}$ At the same time, madrasa attendance may increase social polarization, since it is exclusive to Muslims. This is more likely in case of youths belonging to unrecognized Islamic schools who tend to live in closed communities, and allegedly lack exposure to secular media and the internet.

Third, villages across Bangladesh vary significantly in terms of geographic features and organizational structure (e.g. presence of natural barriers such as rivers, access to the sea, proximity to Hindu-majority Indian districts, NGO presence and so on). Religious mix of the population has varied due to historical factors. Consequently, there exists variation at the community level in dimensions such as connection to urban centres, exposure to people from other faith groups, presence of religious institutions and the extent of economic development. The entry of NGOs in rural communities can be also expected to improve social trust in rural areas (Mondal, 2000; Kabeer and Matin, 2005). NGO presence has arguably made up for poor governance in the social sector and at the same time brought community members closer and facilitated collective action.

\footnotetext{
${ }^{7}$ In-group vs. out-group effects on trust have been studied in a laboratory setting (e.g. Smith, 2011; Tsutsui and Zizzo, 2014). For a theory on how group membership relates to category based procedure of belief formation and perception of trust, see William (2001).

${ }^{8}$ Similarly Arbel, Bar-El, Siniver and Tobol (2014) report a positive association between religious education (and religiosity) and pro-social behaviour such as honesty in Israel.
} 
Fourth, Bangladesh is one of the few developing countries to have experienced significant economic growth over the last twenty years. This positive growth spell followed from the fall of the autocratic regime and the subsequent transition to democracy in 1991. Yet, the quality of public institutions in the country remains poor, and this has led to unfavourable ranking in the global survey on corruption perceptions. ${ }^{9}$ According to Knox (2009), an “institutional trust” deficit has emerged in Bangladesh owing to political instability, corruption and lack of confidence in the democratic process. This in turn can lower social trust. Yet, the determinants of social trust in Bangladeshi villages remains poorly understood. A related study on Bangladesh by Johansson-Stenman et al. (2009) focuses on religion as a determinant of trust. However, trusting attitude is studied drawing a sample only from the most prosperous and institutionally developed administrative division of Bangladesh, namely, Dhaka. Divisions in Bangladesh also vary significantly in terms of religious composition; Dhaka has the lowest share of Hindus in the population. As such, the sample employed by Johansson-Stenman et al. (2009) is unsuitable for exploring the general relationship between institutions, religion, and social trust in rural Bangladesh.

\section{Trust Measures, Sample and Data Description}

\subsection{Measuring trust using survey data}

There are significant differences in the manner in which trust is defined by researchers across disciplines. In the economics literature, the act of trusting is seen as the combination of the prosocial preferences of the person (e.g. reciprocity, altruism) and his/her belief in other people’s trustworthiness (Fehr, 2009; Sapienza, Toldra-Simats, and Zingales 2013). Trust has a strategic element as well as a

\footnotetext{
${ }^{9}$ The 2011 Corruption Perception Index of Transparency International ranks Bangladesh as 120 out of 143 countries.
} 
moralistic component (Bulloch 2013). According to Coleman (1990), people calculate the gains and losses which might result from their decision to trust or not to trust others before they finalize their decision. However, Bachmann (2001) criticizes this conceptualization, arguing that trust should be seen as a mechanism that allows for social interaction instead of being viewed as a (potential) result of rational calculation. ${ }^{10}$ An additional challenge arises in conceptualizing trust in cross-national research. Although trust as a general notion can be viewed as an "etic" or cultureneutral construct that can be universally applied, the specific form of trust, and the specific mechanisms of trust building, may be “emic" or culture/context/situation specific (Zaheer and Zaheer, 2006; Saunders et al 2010; Bachmann and Zaheer 2013)..$^{11}$

Given the debates on the concept of trust and its etic and emic determinants and consequences, how the level of, and disposition to, trust can be empirically measured also remains a contested issue in the related literature. A common approach to measuring inter-personal trust consists of surveying people on whether they trust strangers. Variants of this approach include combining survey items that explicitly refer to trusting behaviour such as lending money and personal belongings to friends (see Glaeser et al. 2000). Naef and Jurgen (2009), and Ben-Ner and Halldorsson (2010), develop additional survey trust scales using three short sentences, and combining three survey measures of trust, respectively. Another approach used mostly in the economics literature directly investigates behaviours that reflect differing

\footnotetext{
${ }^{10}$ For a review of various theories on the origins of trust, see Delhey and Newton (2003). Also see Rousseau, Sitkin, Burt and Camerer (1998) and McKnight and Chervany (2001) on conceptual (and measurable) constructs of trust across several disciplines including economics, sociology and social psychology.

${ }^{11}$ In individualistic and masculine culture, for instance, trust is more likely to be formed through calculative processes while in collectivist and feminine culture, it is based more on confidence that the targets' behaviour can be predicted (Ferrin and Gillespie, 2010).
} 
degrees of trust. This involves fielding trust or investment games where the amount sent is seen as a measure of trust.

In addition to behavioural and survey measures, some researchers prefer a mixed methods approach. This is particularly useful to understand the varied ways in which religion, social distance and norms of trust interact with each other as it allows the concept and analysis of trust to be grounded in a local context (Obadia and Wood, 2011); Whaley and Longoria, 2009; Saunders and Thornhill, 2011). However, a mixed methods approach and/or field experiments are not practical in the case of large surveys, mainly for budgetary reasons. Moreover, while field experiments can gather objective data, questions remain on the sensitivity and validity of the experimental measure in heterogeneous populations. ${ }^{12}$ In this context, WVS type measure provides a practical alternative ${ }^{13}$. Recent studies confirm a significant positive correlation between the experimental (i.e. actual behaviour in the trust game) and survey measures (e.g., Etang, Fielding and Knowles 2012; Johnson and Mislin 2012). ${ }^{14}$ In this study, we therefore rely on WVS type survey measures of trust which is explained in the next section.

\subsection{Survey and sample description}

Data used in this paper comes from a multi-purpose household survey designed by the authors in 2007-8 as part of the World Bank funded project on the "Quality of Secondary School Madrasa Education in Bangladesh” (QSSMEB). Bangladesh is divided administratively into six divisions-Dhaka, Chittagong, Sylhet, Barisal,

\footnotetext{
12 There may be unobserved characteristics of the local population that make inferences about behaviour rather difficult to generalize into other geographic regions (Henrich et al., 2010).

${ }^{13}$ For a discussion on the relative goodness of survey based measures of trust, see Sapienza, Toldra and Zingales (2007) and Thöni, Tyran and Wengström (2012). Also see Bulloch (2013) who reviews five most widely used survey measures of trust as well as the literature on the conceptualization of trust.

${ }^{14}$ However, evidence also shows that the WVS question mostly captures the belief-based component of trust (Sapienza, Toldra-Simats, and Zingales 2013). In addition, Uslaner (2002) points out that WVS type measures of trust reflect moralistic rather than experience-based trust in others.
} 
Rajshahi and Khulna. Therefore we first randomly selected 12 districts from these divisions. ${ }^{15}$ The probability proportional to size (PPS) method of random sampling was used, based on division/district level population data from the 2001 national population census. Two sub-districts were randomly selected from each of the selected 12 districts. Then two unions were randomly selected from each of the selected 24 sub-districts.

For each of the 48 sample Unions, we randomly selected two villages using PPS based on village-level population data from the 2001 national census. A complete census of all households was carried out in each sample village. From the census household frame, 25 households were randomly selected from each village. Then, a detailed multi-module household survey was administered (e.g., complete roster, education history, employment status, assets, consumption and so on). This led to detailed data on 2,400 households. ${ }^{16}$

The main respondents were heads of sample households in our survey. In order to measure trust, we adapted the trust question used in the World Values Survey - "Generally speaking, would you say that most people can be trusted or that you need to be very careful when dealing with people?" The average response to the generalized trust question is the standard measure of social capital/trust in the empirical cross-country literature (e.g. Knack and Keefer, 1997; Zak and Knack, 2001). However, one may be concerned about the exact content of this measure of trust. A high level of trust produces a large amount of general trust given that the radius of trust is wide (Delhey et al 2011). A survey respondent's interpretation of who "most people" are (or the trust radius) would differ under different circumstances in different societies (Glaeser et al., 2000; Beugelsdijk, 2006). Moreover, respondents

\footnotetext{
${ }^{15}$ The resultant sample districts are Bogra, Kurigram, Jessore, Barisal, Faridpur, Mymensingh, Sylhet, Moulovibazar, Comilla, Chandpur, Lakshmipur and Chittagong.

For further details on the QSSMEB survey, see Asadullah and Chaudhury (2016).
} 
of a given religious group can have low out-group trust and yet demonstrate high ingroup trust -- response to the WVS trust question per se does not distinguish between particularized and generalized trust. The former refers to an intimate trust in people close to the truster and is described as thick trust. The latter is "diffuse trust" (i.e. an abstract trust in people in general). Nonetheless, evidence indicates a significant overlap between these two dimensions of interpersonal trust. In other words, individuals who place much trust in friends/family members/coreligionists are also more likely to trust people in general (Freitag and Traunmüller, 2009; Sturgis and Smith, 2010). ${ }^{17}$

To partially deal with some of the above issue, we go beyond a single-item measure of trust by incorporating a range of additional measures that specify the circle of "most people". This is based on answers to the question: "I will ask you how much trust do you have in individuals of different communities/groups”, for the following categories: Muslims, Christians, Hindus, Buddhist, foreigners, NGO workers and people you meet for the first time (i.e. strangers), on a scale of 1 (don't trust at all) to 5 (trust completely). Response to these questions together with the WVS question on generalized trust allows us to capture in-group and out-group trust as well as the possibility that respondents can have low generalized, but high particularized, trust.

To proxy for perceived institutional trust, we use responses to the question "How much confidence do you have in the following institutions/organizations?” on a scale of 1 to 4 (where $1=$ low; $4=$ high) for each of the following: Religious institutions, Bank, NGO, Military, Police, Judiciary, Government, religion based

\footnotetext{
${ }^{17}$ More recent evidence shows that the radius problem is not too serious. Comparing responses of the standard trust question with measures of in-group and out-group trust for 51 countries, Delhey, Newton, and Welzel (2011) find that "most people" in the standard question predominantly implies "out-groups". This confirms that WVS question is a measure of general trust in others.
} 
political parties, non-religious political parties and rural elites. Responses are aggregated, and values are inverted so that the index has a theoretical range of 10 ("'no confidence at all’) to 40 (“"complete confidence”).$^{18}$ Since we have enquired both religious (i.e. Islamic) and non-religious institutions, there is variation in the religious composition of employees in the members of different institutions. This ensures that the aggregate index is not just a proxy of trust in members of different religious groups.

Lack of institutional trust can also be a proxy for lack of general (i.e. social) trust in rural areas. Therefore, we also repeat the WVS question on generalized trust (as discussed above) in the accompanying census conducted in our 96 sample villages. We then construct a measure of trust at the community level aggregating response to this from village census records. Lastly, dissatisfied individuals in rural Bangladesh may live in under-provided areas that lack access to basic infrastructure such as roads and health care facilities. Therefore, we additionally create an index of village development that ranges between 0 (no facilities) and 7 (having a police station, post office, health care centre, pucca road, telephone line, electricity and satellite dish). These aggregated indices are used in the regression analysis in Section 4 to account for factors that could confound the relationship between inter-personal and perceived institution trust.

To get a first insight in the relationship between trust and religious affiliation,

Table 1 reports sample household-head's responses to various trust questions

\footnotetext{
${ }^{18}$ The state and non-state institutions/organizations included in the index are widely believed to play critical role in the delivery of various public services and/or protecting citizen rights in rural Bangladesh; see for instance Knox (2009), Mondol (2000), and Kabeer and Matin (2005). As previously pointed out, Bangladesh has a poor system of governance. Individuals in their daily lives often have to deal with corrupt civil servants, and even use bribes to access public health facilities, legal services and secure protection from the police. Dysfunctional public institutions may in turn increase support for non-state institutions (e.g. NGOs, religious bodies).
} 
separately by religious affiliation of the respondents. ${ }^{19}$ A number of patterns emerge from Table 1. First, there is no religion effect in general trust questions. In other words, Hindus do not appear to be distrustful of the wider society. Second, significant Hindu-Muslim gaps exist when it comes to trusting Muslims, Hindus, Christians, Buddhist, and NGO workers. Third, size of between group differences in trust varies Hindus trust Muslims more (mean score of 3.89) than Muslims trust Hindus (mean score of 2.44). Fourth, Hindus trust non-Muslims of all denominations and NGO workers more compared to Muslims.

Table 1: Survey response to trust questions by religion

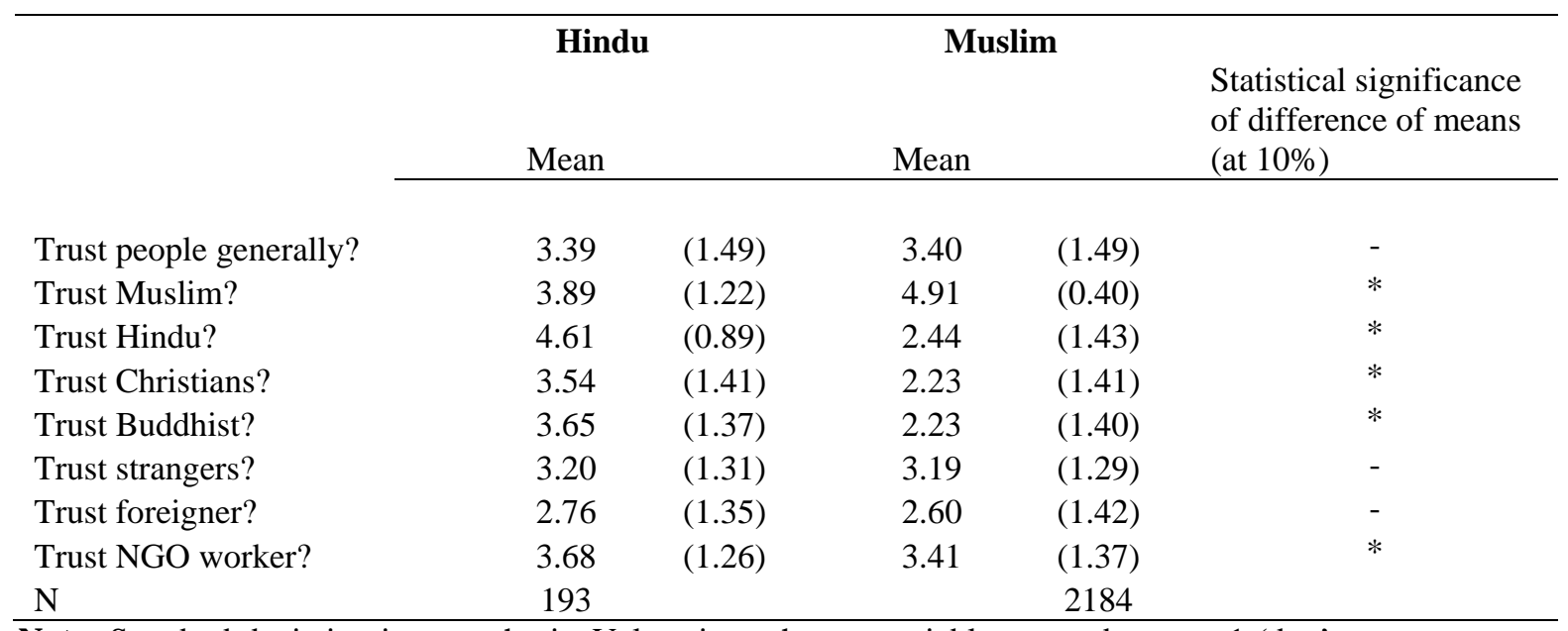

Note: Standard deviation in parenthesis. Values in each trust variable ranges between 1 (don't trust at all) and 5 (fully trust). * indicates significance of between-group difference.

Overall, Table 1 suggests significant social distance between Hindu and Muslim faith communities. However, between-group differences could be driven by a number of factors. Analysis of summary statistics (see Appendix Table 2) does not suggest that, compared to Muslims, Hindus do not appear to be disadvantaged in terms of socio-economic indicators (such as education, household expenditure and so on). However, "Hindu villages" do have fewer mosques, and appear to be less

19 The sample size corresponding to Christian and Buddhist households is too small to permit meaningful statistical analysis. Therefore, our analyses throughout is restricted to Hindu and Muslim households. 
developed in terms of provision of pucca roads. Most importantly, Hindus tend to live in villages with a higher proportion of non-Muslim households. As a matter of fact, the Hindu population in Bangladesh has a higher concentration in certain districts, some of which border the Hindu majority country India, and are isolated from the capital city, Dhaka. Fortunately, our sample households are drawn from a total of 12 districts, where four come from Rajshahi, Jessore and Barisal divisions, widely known as relatively backward regions of Bangladesh. Of the remaining, six belong to Dhaka and Chittagong divisions, which have experienced significant economic growth and large scale decline in poverty in the last decade. Households in these divisions also differ in terms of proximity to urban centres and markets. Therefore, it is unsurprising that Appendix Table 1 confirms significant variation across divisions in trust data. This highlights the importance of employing a nationally spread out sample to study correlates of trust. At the same time, it raises the possibility that bivariate findings reported in Table 1 could be driven by between-religion differences in institutional trust, and other individual and community level correlates, and enumerator's religious identity. In the next section, we therefore discuss social and individual determinants of trust, but do so holding differences across divisions and districts constant.

Lastly, as discussed in Section 3.1, pro-sociality and the meanings of trust and distrust may vary across countries and religious communities in different ways. Given the universal and culture-specific aspects of trust (Ferrin and Gillespie, 2010), additional modifications are required to account for emic constructs and local practices (Fulmer and Gelfand 2012). In this study, we have not conducted focusgroup analysis with members of Hindu and Muslim communities to examine the “emic” aspect of trust. By adopting questions from the World Values Survey in a structured survey, our approach mostly presents an etic account of trust attitude, since 
we assume no ethnocentric bias. This remains a limitation of our data. Among other limitations, we were not able to distinguish between belief and preference-based trust, since it would additionally require panel data with information on past trusting behaviour, or an experimental design.

\section{Regression results}

In this section, we present ordered Probit regression estimates of the determinants of social trust. Responses to a total of eight trust-related questions are used as dependent variables. The main individual-specific covariates of interest are religious affiliation, educational status and confidence in institutions. These are based on regressions with extensive controls for a number of factors that are considered important in existing empirical studies on social trust as discussed in Section 2. These include individual characteristics such as marital status, age, gender and socio-economic conditions of the household such as per capita monthly expenditure, physical condition of the home, wealth relative to other villagers and experience of negative shock. To further investigate the effect of aggregate factors, we control for community characteristics such as the presence of pucca roads, electricity, NGO and non-Muslim population in the village, number of mosques in the village, village-level economic inequality and the village being semi-urban-In the subsequent section, we first discuss the results for the full sample, followed by a discussion of the determinants of trust in the Muslim sub-sample. Lastly, the section discuses results from robustness analysis.

\subsection{Determinants of trust: full sample analysis}

The main results are presented in Table 2 . We find a statistically significant and negative coefficient on the Hindu dummy in the regression model on trusting Muslims. On the other hand, the Hindu dummy is positive and significant in the regression model on trusting Hindus. In other words, both Hindus and Muslims trust 
others from their own religion more than they trust people from other religions. This finding of inter-group distance is consistent with new evidence on trust from India, a country with large Hindu and Muslim populations (e.g. Chuah et al. 201320). Our findings are also in line with those by Johansson-Stenman et al. (2009). However, in contrast to Johansson-Stenman et al., we did not find that Hindus trust other people less in general. In addition, we find that Hindus trust Christians and Buddhist more than Muslims. Hindus also trust NGO workers more than Muslims.

Among other individual characteristics, we find no systematic influence of schooling. ${ }^{21}$ Individuals with no formal education are found to significantly trust more in general and Muslims in particular; but no clear pattern is noted with regards to trusting non-Muslims. Individuals who experienced no economic shock in the past twelve months were found to trust Hindus, Christians, Buddhist and strangers significantly more. The finding is consistent with the hypothesis that a history of negative events is associated with a low level of trust (e.g. see Alesina and La Ferrara, 2002).

Turning to our proxy for institutional trust, the coefficient on confidence index is systematically negative and statistically significant in all specifications irrespective of the dependent variable. In other words, low institutional trust not only undermines trust in general, and towards individuals from particular religious denominations, it also undermines trust towards other non-religious institutions such as NGOs working for relief, poverty reduction, gender equality and so on. ${ }^{22}$ This is an important result in the context of Bangladesh, a poorly governed and highly corrupt country. It may be

\footnotetext{
${ }^{20}$ In their field experiment employing inter-ethnic trust game on urban Muslims and Hindus in Mumbai, Chuah et al. find that compared to Muslims, Hindus generally have greater trust and expectations of others' trust.

${ }^{21}$ This contrasts with other studies in the literature that report education as one of the most consistent predictors of generalised trust (see Glaeser et al, 2000; Leigh, 2006).

${ }^{22}$ There are few NGOs (e.g. Islamic Relief) that have religious motivates. However, such NGOs do not have a nation-wide presence in Bangladesh.
} 
argued that in rural developing countries, this finding reflects the influence of poverty: individuals who suffer from corruption (i.e. weak institutions) are likely to have lower institutional and social trust. However, our model already includes extensive controls for household poverty. One may argue that the confidence index effect in Table 2 captures the effect of community-wide trust: individuals reporting a low confidence index belong to villages with poor institutions. However, our results hold with controls for village development level (e.g. access to electricity, pucca roads). Moreover, we repeated the regression analysis (model 2) by adding a village level measure of generalized trust question. ${ }^{23}$ However, the effect of confidence index remained significant.

Model 2 for each dependant variable includes six village characteristics. Village economic development (proxied by road condition and electricity access) is not systematically associated to trust. Similarly, we find no evidence that more unequal villages (measuring in terms of land ownership) is associated with lower trust. We also revisited this result using educational inequality as an alternative proxy. However, this did not yield a significant relationship between trust and inequality. Here, an interesting finding is that NGO presence (defined in terms of presence of both Grameen Bank and BRAC) does not have any systematic effect on the level of social trust towards various religious groups. It is also insignificant as a determinant of generalized trust. Contrary to common belief, NGO presence significantly lowers trust in NGO workers and foreigners. Villages that attract large NGOs are significantly poorer and farther away from urban centres. This may explain the reason residents are distrustful of outsiders such as NGO workers and foreigners. However,

\footnotetext{
${ }^{23}$ Our household survey was accompanied by a village-wide short population census. The resultant dataset comprises of information on 24,000 households. Each head of these households was asked to reply to the generalized trust question. We averaged their responses at the village level to construct the aggregate trust question.
} 
our analysis already accounts for location, level of village development and household poverty.

Lastly, findings related to Hindu-Muslim difference are robust to control for village characteristics. This is an important result, since Hindu minorities in Bangladesh often cluster together in certain villages. Their trusting attitudes in this case could potentially capture the effect of the ethnic composition of the village on trust attitudes. In sum, our results strikingly confirm those obtained with the standard measure of trust. These findings are robust to control for a wide range of individual and community level correlates, and are consistent with the results of a previous study on social trust in Bangladesh that employed data from only one division (Stenman et al. 2008). 
Table 2: Ordered Probit estimates of determinants of social trust

\begin{tabular}{|c|c|c|c|c|c|c|c|c|}
\hline & Trust Muslim? & Trust Hindu? & Trust Christian? & Trust Buddhist & ?Trust strangers? & Trust foreigners? & Trust people in general? & Trust NGO worker? \\
\hline Female & $\begin{array}{l}-0.074 \\
(0.52)\end{array}$ & $\begin{array}{l}-0.118 \\
(1.49)\end{array}$ & $\begin{array}{c}-0.161 \\
(1.93)+\end{array}$ & $\begin{array}{c}-0.189 \\
(2.20)^{*}\end{array}$ & $\begin{array}{c}0.126 \\
(1.64)+\end{array}$ & $\begin{array}{l}-0.147 \\
(1.58)\end{array}$ & $\begin{array}{l}-0.034 \\
(0.43)\end{array}$ & $\begin{array}{l}0.037 \\
(0.47)\end{array}$ \\
\hline Hindu & $\begin{array}{c}-1.826 \\
(14.82)^{* *}\end{array}$ & $\begin{array}{c}2.169 \\
(18.82)^{* *}\end{array}$ & $\begin{array}{c}1.095 \\
(10.75)^{* *}\end{array}$ & $\begin{array}{c}1.178 \\
(11.47)^{* *}\end{array}$ & $\begin{array}{l}0.056 \\
(0.61)\end{array}$ & $\begin{array}{c}0.193 \\
(1.82)+\end{array}$ & $\begin{array}{l}-0.092 \\
(0.97)\end{array}$ & $\begin{array}{c}0.21 \\
(2.11)^{*}\end{array}$ \\
\hline Married & $\begin{array}{l}-0.246 \\
(1.31)\end{array}$ & $\begin{array}{l}-0.065 \\
(0.65)\end{array}$ & $\begin{array}{l}-0.157 \\
(1.49)\end{array}$ & $\begin{array}{l}-0.112 \\
(1.04)\end{array}$ & $\begin{array}{l}-0.13 \\
(1.35)\end{array}$ & $\begin{array}{c}-0.22 \\
(1.93)^{+}\end{array}$ & $\begin{array}{l}0.037 \\
(0.38)\end{array}$ & $\begin{array}{l}-0.033 \\
(0.33)\end{array}$ \\
\hline Age & $\begin{array}{l}0.017 \\
(0.68)\end{array}$ & $\begin{array}{l}0.018 \\
(1.31)\end{array}$ & $\begin{array}{l}0.021 \\
(1.41)\end{array}$ & $\begin{array}{l}0.012 \\
(0.81)\end{array}$ & $\begin{array}{l}0.003 \\
(0.26)\end{array}$ & $\begin{array}{l}0.005 \\
(0.34)\end{array}$ & $\begin{array}{c}0.024 \\
(1.77)^{+}\end{array}$ & $\begin{array}{c}0.025 \\
(1.76)^{+}\end{array}$ \\
\hline No education & $\begin{array}{c}0.262 \\
(2.84)^{* *}\end{array}$ & $\begin{array}{c}0.02 \\
(0.39)\end{array}$ & $\begin{array}{l}-0.027 \\
(0.51)\end{array}$ & $\begin{array}{l}-0.044 \\
(0.79)\end{array}$ & $\begin{array}{c}0.101 \\
(2.02)^{*}\end{array}$ & $\begin{array}{l}0.024 \\
(0.42)\end{array}$ & $\begin{array}{c}0.117 \\
(2.27)^{*}\end{array}$ & $\begin{array}{c}0.098 \\
(1.91)^{+}\end{array}$ \\
\hline Log of per capita household expenditure & $\begin{array}{c}0.239 \\
(2.09)^{*}\end{array}$ & $\begin{array}{l}0.031 \\
(0.48)\end{array}$ & $\begin{array}{l}0.099 \\
(1.45)\end{array}$ & $\begin{array}{l}0.089 \\
(1.28)\end{array}$ & $\begin{array}{c}0.16 \\
(2.56)^{*}\end{array}$ & $\begin{array}{c}0.176 \\
(2.38)^{*}\end{array}$ & $\begin{array}{l}-0.043 \\
(0.68)\end{array}$ & $\begin{array}{c}-0.238 \\
(3.72)^{* *}\end{array}$ \\
\hline House wall made of mud & $\begin{array}{c}0.262 \\
(2.59)^{* *}\end{array}$ & $\begin{array}{l}0.019 \\
(0.34)\end{array}$ & $\begin{array}{l}0.051 \\
(0.85)\end{array}$ & $\begin{array}{l}0.059 \\
(0.97)\end{array}$ & $\begin{array}{l}0.075 \\
(1.36)\end{array}$ & $\begin{array}{c}0.123 \\
(1.94)^{+}\end{array}$ & $\begin{array}{l}-0.034 \\
(0.62)\end{array}$ & $\begin{array}{l}0.047 \\
(0.83)\end{array}$ \\
\hline No economic shock & $\begin{array}{l}0.089 \\
(0.99)\end{array}$ & $\begin{array}{c}0.091 \\
(1.81)^{+}\end{array}$ & $\begin{array}{c}0.124 \\
(2.36)^{*}\end{array}$ & $\begin{array}{c}0.151 \\
(2.84)^{* *}\end{array}$ & $\begin{array}{c}0.112 \\
(2.30)^{*}\end{array}$ & $\begin{array}{c}-0.03 \\
(0.53)\end{array}$ & $\begin{array}{l}-0.099 \\
(1.99)^{*}\end{array}$ & $\begin{array}{l}0.016 \\
(0.32)\end{array}$ \\
\hline Confidence index & $\begin{array}{c}0.057 \\
(6.98)^{* *}\end{array}$ & $\begin{array}{c}0.039 \\
(8.19)^{* *}\end{array}$ & $\begin{array}{c}0.046 \\
(9.14)^{* *}\end{array}$ & $\begin{array}{c}0.046 \\
(8.98)^{* *}\end{array}$ & $\begin{array}{c}0.032 \\
(6.97)^{* *}\end{array}$ & $\begin{array}{c}0.031 \\
(5.61)^{* *}\end{array}$ & $\begin{array}{c}0.034 \\
(7.40)^{* *}\end{array}$ & $\begin{array}{c}0.102 \\
(20.52)^{* *}\end{array}$ \\
\hline Wealth relative to others & $\begin{array}{c}0.051 \\
(1.13)\end{array}$ & $\begin{array}{c}0.01 \\
(0.37)\end{array}$ & $\begin{array}{l}0.044 \\
(1.62)\end{array}$ & $\begin{array}{c}0.058 \\
(2.11)^{*}\end{array}$ & $\begin{array}{l}0.022 \\
(0.91)\end{array}$ & $\begin{array}{c}0.04 \\
(1.42)\end{array}$ & $\begin{array}{l}0.014 \\
(0.56)\end{array}$ & $\begin{array}{l}-0.001 \\
(0.04)\end{array}$ \\
\hline Village has non-Muslims & $\begin{array}{l}-0.496 \\
(1.18)\end{array}$ & $\begin{array}{l}0.162 \\
(0.58)\end{array}$ & $\begin{array}{l}-0.151 \\
(0.52)\end{array}$ & $\begin{array}{l}0.001 \\
(0.0)\end{array}$ & $\begin{array}{l}-0.545 \\
(2.02)^{*}\end{array}$ & $\begin{array}{c}-0.526 \\
(1.67)^{+}\end{array}$ & $\begin{array}{l}-0.268 \\
(0.99)\end{array}$ & $\begin{array}{l}-0.085 \\
(0.31)\end{array}$ \\
\hline Village has pucca road & $\begin{array}{l}0.145 \\
(1.39)\end{array}$ & $\begin{array}{l}-0.02 \\
(0.35)\end{array}$ & $\begin{array}{l}0.063 \\
(1.06)\end{array}$ & $\begin{array}{l}0.046 \\
(0.77)\end{array}$ & $\begin{array}{c}-0.098 \\
(1.79)+\end{array}$ & $\begin{array}{l}-0.006 \\
(0.12)\end{array}$ & $\begin{array}{l}-0.065 \\
(1.15)\end{array}$ & $\begin{array}{l}-0.045 \\
(0.81)\end{array}$ \\
\hline Village has electricity & $\begin{array}{l}-0.144 \\
(0.86)\end{array}$ & $\begin{array}{l}0.113 \\
(1.32)\end{array}$ & $\begin{array}{l}0.043 \\
(0.47)\end{array}$ & $\begin{array}{l}0.104 \\
(1.12)\end{array}$ & $\begin{array}{l}0.039 \\
(0.48)\end{array}$ & $\begin{array}{l}0.082 \\
(0.88)\end{array}$ & $\begin{array}{l}-0.021 \\
(0.25)\end{array}$ & $\begin{array}{l}0.051 \\
(0.60)\end{array}$ \\
\hline \# of mosques in the village & $\begin{array}{l}-0.035 \\
(1.03)\end{array}$ & $\begin{array}{l}-0.031 \\
(1.31)\end{array}$ & $\begin{array}{l}0.003 \\
(0.11)\end{array}$ & $\begin{array}{l}-0.01 \\
(0.39)\end{array}$ & $\begin{array}{l}-0.051 \\
(2.22)^{*}\end{array}$ & $\begin{array}{l}-0.008 \\
(0.28)\end{array}$ & $\begin{array}{l}-0.015 \\
(0.64)\end{array}$ & $\begin{array}{l}-0.026 \\
(1.12)\end{array}$ \\
\hline Village semi urban & $\begin{array}{l}-0.142 \\
(1.03)\end{array}$ & $\begin{array}{c}0.34 \\
(3.64)^{* *}\end{array}$ & $\begin{array}{c}0.377 \\
(3.83)^{* *}\end{array}$ & $\begin{array}{c}0.363 \\
(3.63)^{* *}\end{array}$ & $\begin{array}{l}-0.024 \\
(0.26)\end{array}$ & $\begin{array}{l}-0.051 \\
(0.47)\end{array}$ & $\begin{array}{l}0.036 \\
(0.39)\end{array}$ & $\begin{array}{l}-0.079 \\
(0.88)\end{array}$ \\
\hline Village economic inequality & $\begin{array}{l}0.001 \\
(0.67)\end{array}$ & $\begin{array}{c}0 \\
(0.42)\end{array}$ & $\begin{array}{c}0 \\
(0.02)\end{array}$ & $\begin{array}{l}0.001 \\
(0.37)\end{array}$ & $\begin{array}{l}0.001 \\
(1.16)\end{array}$ & $\begin{array}{c}0 \\
(0.47)\end{array}$ & $\begin{array}{c}0 \\
(0.06)\end{array}$ & $\begin{array}{l}-0.001 \\
(1.17)\end{array}$ \\
\hline Village has NGO presence & $\begin{array}{l}0.112 \\
(1.17) \\
\end{array}$ & $\begin{array}{c}-0.095 \\
(1.71)^{+}\end{array}$ & $\begin{array}{l}-0.049 \\
(0.85) \\
\end{array}$ & $\begin{array}{r}-0.087 \\
(1.48) \\
\end{array}$ & $\begin{array}{l}0.043 \\
(0.82) \\
\end{array}$ & $\begin{array}{c}-0.113 \\
(1.78)^{+}\end{array}$ & $\begin{array}{l}-0.005 \\
(0.09) \\
\end{array}$ & $\begin{array}{l}-0.045 \\
(0.83) \\
\end{array}$ \\
\hline $\begin{array}{l}\text { Observations } \\
\text { Psudo } R^{2}\end{array}$ & 2309 & 2256 & 2081 & 2009 & 2187 & 1686 & 2291 & 2175 \\
\hline
\end{tabular}

Note: (a) regressions include control for district fixed effects; (b) standard errors are clustered at the village level; (c) t-statistics in parenthesis; (d) regression model includes a square term of respondent age; (e) "trust NGO worker" regression uses a parsimonious version of the confidence index, ranging between 9 and 36 , that takes out confidence in NGO from the index. 


\subsection{Determinants of trust: Muslim respondents}

An important area in which Muslim societies differ from their Western counterparts is in the structure of the education system. Many are educated in Islamic schools that exclude students from non-Muslim faiths. This in turn can create social distance, and undermine inter-community faiths. Moreover, imams and clerics working in mosques and other religious institutions play an important role in community decision making in rural societies. Consequently, they are likely to have an influence in the way Muslims value and engage with individuals outside their faith groups.

In order to better understand the factors that determine the level of trust among Muslims, the religious majority in Bangladesh, we reproduced results from Table 2 by discarding observations on Hindus. Results are reported in Table 3. However, the regression specification is modified in three ways. First, in addition to the earlier measure of institutional trust, we now include an index capturing confidence in religious institutions (e.g. mosque). ${ }^{24}$ Second, we include a measure of religiosity (i.e. frequency of daily prayers). Lastly, we include an indicator to capture Islamic school attendance.

A number of findings follow from Table 3. First, Muslims who report greater confidence in religious institutions are significantly more likely to trust fellow Muslims. But they trust non-Muslims (Hindu, Christian and Buddhist), NGO workers and foreigners significantly less. Moreover, they also trust people in general significantly less. Second, religious participation (measured by prayer frequency) appears to have no significant effect on social trust. This is consistent with Tan (2006)

\footnotetext{
${ }^{24}$ This separation is important because even following modernization and economic development, trust in state/political institutions may be low as opposed to religious institutions (Charles 2010).
} 
and Johansson-Stenman et al. (2009). ${ }^{25}$ It is also noteworthy that there are a few exceptions. Religious Muslims are more likely to trust strangers, but are significantly less likely to trust Hindus and Christians. Third, we find that madrasa graduates are significantly less likely to trust Hindus, Christians, Budhists, strangers, foreigners and NGO workers. Since our model already controls for household income, this finding is unlikely to reflect poorer socio-economic conditions of madrasa graduates. ${ }^{26}$ Meanwhile, Hindu-Muslim trust gaps remain even after we purge the sample of madrasa graduates, confirming that trust towards other religious groups is low across school types. ${ }^{27}$ Overall, religious Muslims and those educated in madrasas do not demonstrate high particularised trust (i.e. trust towards their own kind) but they appear not to trust people who are different from themselves, hence showing outgroup discrimination.

\footnotetext{
${ }^{25}$ Sarkissian (2012) also points out that daily prayer is associated with less civic engagement in some Muslim countries.

${ }^{26}$ Our finding contrasts with the recent international evidence for other Muslim countries. Using experimental data on male students, Delavande and Zafar (2015) find that madrasa respondents in Pakistan are amongst the most trusting and expect others to be the most trustworthy compared to those belonging to non-madrasa institutions. Their finding could be partly owing to the fact that sample students belong to tertiary degree awarding madrasa and non-madrasa educational institutions in urban Pakistan.

${ }^{27}$ In our sample, less than $4 \%$ of respondents were educated in a madrasa.
} 
Table 3: Ordered Probit estimates of determinants of social trust, Muslim respondents only

\begin{tabular}{|c|c|c|c|c|c|c|c|c|}
\hline & $\begin{array}{c}\text { Trust } \\
\text { Muslim? }\end{array}$ & $\begin{array}{c}\text { Trust } \\
\text { Hindu? }\end{array}$ & $\begin{array}{c}\text { Trust } \\
\text { Christian? }\end{array}$ & $\begin{array}{c}\text { Trust } \\
\text { Buddhist? }\end{array}$ & $\begin{array}{c}\text { Trust } \\
\text { strangers? }\end{array}$ & $\begin{array}{c}\text { Trust } \\
\text { foreigners? }\end{array}$ & $\begin{array}{l}\text { Trust people } \\
\text { in general? }\end{array}$ & $\begin{array}{c}\text { Trust NGO } \\
\text { worker? }\end{array}$ \\
\hline Female & $\begin{array}{l}-0.067 \\
(0.43)\end{array}$ & $\begin{array}{l}-0.031 \\
(0.38)\end{array}$ & $\begin{array}{l}-0.073 \\
(0.85)\end{array}$ & $\begin{array}{l}-0.082 \\
(0.93)\end{array}$ & $\begin{array}{c}0.138 \\
(1.75)^{+}\end{array}$ & $\begin{array}{l}-0.081 \\
(0.85)\end{array}$ & $\begin{array}{c}-0.012 \\
(0.15)\end{array}$ & $\begin{array}{l}0.027 \\
(0.34)\end{array}$ \\
\hline Married & $\begin{array}{l}-0.377 \\
(1.59)\end{array}$ & $\begin{array}{l}-0.018 \\
(0.17)\end{array}$ & $\begin{array}{l}-0.084 \\
(0.78)\end{array}$ & $\begin{array}{l}-0.057 \\
(0.51)\end{array}$ & $\begin{array}{l}-0.064 \\
(0.65)\end{array}$ & $\begin{array}{l}-0.152 \\
(1.32)\end{array}$ & $\begin{array}{l}0.102 \\
(1.01)\end{array}$ & $\begin{array}{l}-0.047 \\
(0.45)\end{array}$ \\
\hline Age & $\begin{array}{l}0.012 \\
(0.42)\end{array}$ & $\begin{array}{c}0.023 \\
(1.66)^{+}\end{array}$ & $\begin{array}{l}0.019 \\
(1.25)\end{array}$ & $\begin{array}{l}0.014 \\
(0.94)\end{array}$ & $\begin{array}{l}0.001 \\
(0.07)\end{array}$ & $\begin{array}{c}0 \\
(0.01)\end{array}$ & $\begin{array}{l}0.008 \\
(0.61)\end{array}$ & $\begin{array}{c}0.029 \\
(2.00)^{*}\end{array}$ \\
\hline No education & $\begin{array}{c}0.197 \\
(1.87)^{+}\end{array}$ & $\begin{array}{l}-0.035 \\
(0.64)\end{array}$ & $\begin{array}{l}-0.069 \\
(1.19)\end{array}$ & $\begin{array}{l}-0.095 \\
(1.62)\end{array}$ & $\begin{array}{l}0.071 \\
(1.34)\end{array}$ & $\begin{array}{l}-0.01 \\
(0.17)\end{array}$ & $\begin{array}{c}0.169 \\
(3.15)^{* *}\end{array}$ & $\begin{array}{l}0.045 \\
(0.85)\end{array}$ \\
\hline Log of per capita household expenditure & $\begin{array}{l}0.152 \\
(1.21)\end{array}$ & $\begin{array}{l}-0.079 \\
(1.24)\end{array}$ & $\begin{array}{c}-0.032 \\
(0.47)\end{array}$ & $\begin{array}{l}-0.048 \\
(0.74)\end{array}$ & $\begin{array}{l}0.087 \\
(1.39)\end{array}$ & $\begin{array}{l}0.082 \\
(1.11)\end{array}$ & $\begin{array}{l}0.072 \\
(1.15)\end{array}$ & $\begin{array}{c}-0.246 \\
(3.87)^{* *}\end{array}$ \\
\hline House wall made of mud & $\begin{array}{c}0.336 \\
(3.01)^{* *}\end{array}$ & $\begin{array}{l}-0.075 \\
(1.35)\end{array}$ & $\begin{array}{l}-0.038 \\
(0.64)\end{array}$ & $\begin{array}{l}-0.047 \\
(0.79)\end{array}$ & $\begin{array}{l}-0.026 \\
(0.48)\end{array}$ & $\begin{array}{l}0.012 \\
(0.22)\end{array}$ & $\begin{array}{l}-0.073 \\
(1.34)\end{array}$ & $\begin{array}{l}0.059 \\
(1.09)\end{array}$ \\
\hline No economic shock & $\begin{array}{l}0.129 \\
(1.26)\end{array}$ & $\begin{array}{c}0.117 \\
(2.30)^{*}\end{array}$ & $\begin{array}{c}0.156 \\
(2.90)^{* *}\end{array}$ & $\begin{array}{c}0.177 \\
(3.24)^{* *}\end{array}$ & $\begin{array}{c}0.143 \\
(2.89)^{* *}\end{array}$ & $\begin{array}{l}0.047 \\
(0.82)\end{array}$ & $\begin{array}{l}-0.087 \\
(1.73)+\end{array}$ & $\begin{array}{l}0.029 \\
(0.58)\end{array}$ \\
\hline Wealth relative to others & $\begin{array}{l}0.036 \\
(0.71)\end{array}$ & $\begin{array}{l}0.019 \\
(0.71)\end{array}$ & $\begin{array}{l}0.039 \\
(1.39)\end{array}$ & $\begin{array}{l}0.044 \\
(1.58)\end{array}$ & $\begin{array}{l}-0.005 \\
(0.21)\end{array}$ & $\begin{array}{l}0.003 \\
(0.11)\end{array}$ & $\begin{array}{l}-0.009 \\
(0.34)\end{array}$ & $\begin{array}{l}-0.009 \\
(0.36)\end{array}$ \\
\hline Confidence index (non-religious institutions) & $\begin{array}{c}0.045 \\
(3.87)^{* *}\end{array}$ & $\begin{array}{c}0.035 \\
(5.61)^{* *}\end{array}$ & $\begin{array}{c}0.053 \\
(7.87)^{* *}\end{array}$ & $\begin{array}{c}0.057 \\
(8.27)^{* *}\end{array}$ & $\begin{array}{c}0.039 \\
(6.46)^{* *}\end{array}$ & $\begin{array}{c}0.04 \\
(5.56)^{* *}\end{array}$ & $\begin{array}{c}0.036 \\
(5.92)^{* *}\end{array}$ & $\begin{array}{c}0.086 \\
(13.74)^{* *}\end{array}$ \\
\hline Confidence index (religious institutions) & $\begin{array}{l}(0.082) \\
(2.37)^{*}\end{array}$ & $\begin{array}{c}(0.025) \\
(1.41)\end{array}$ & $\begin{array}{c}(0.003) \\
(0.14)\end{array}$ & $\begin{array}{c}(0.015) \\
(0.77)\end{array}$ & $\begin{array}{c}(0.019) \\
(1.06)\end{array}$ & $\begin{array}{l}(0.036) \\
(1.71)^{+}\end{array}$ & $\begin{array}{c}(0.04) \\
(2.29)^{*}\end{array}$ & $\begin{array}{c}(0.008) \\
(0.47)\end{array}$ \\
\hline Prays daily & $\begin{array}{l}0.064 \\
(0.62)\end{array}$ & $\begin{array}{l}-0.127 \\
(2.37)^{*}\end{array}$ & $\begin{array}{l}-0.097 \\
(1.70)^{+}\end{array}$ & $\begin{array}{l}-0.087 \\
(1.49)\end{array}$ & $\begin{array}{c}0.17 \\
(3.26)^{* *}\end{array}$ & $\begin{array}{l}0.055 \\
(0.91)\end{array}$ & $\begin{array}{l}-0.043 \\
(0.83)\end{array}$ & $\begin{array}{l}-0.075 \\
(1.43)\end{array}$ \\
\hline Attended Islamic school & $\begin{array}{l}-0.206 \\
(0.88)\end{array}$ & $\begin{array}{c}-0.321 \\
(2.41)^{*}\end{array}$ & $\begin{array}{c}-0.28 \\
(2.01)^{*}\end{array}$ & $\begin{array}{c}-0.24 \\
(1.73)+\end{array}$ & $\begin{array}{c}-0.352 \\
(2.74)^{* *}\end{array}$ & $\begin{array}{l}-0.339 \\
(2.30)^{*}\end{array}$ & $\begin{array}{l}0.161 \\
(1.22)\end{array}$ & $\begin{array}{c}-0.358 \\
(2.72)^{* *}\end{array}$ \\
\hline Village has non-Muslims & $\begin{array}{l}-1.059 \\
(2.23)^{*}\end{array}$ & $\begin{array}{l}-0.254 \\
(0.99)\end{array}$ & $\begin{array}{l}-0.462 \\
(1.66)+\end{array}$ & $\begin{array}{l}-0.239 \\
(0.86)\end{array}$ & $\begin{array}{l}-0.546 \\
(2.17)^{*}\end{array}$ & $\begin{array}{l}-0.476 \\
(1.62)\end{array}$ & $\begin{array}{c}0.921 \\
(3.59)^{* *}\end{array}$ & $\begin{array}{l}-0.446 \\
(1.75)^{+}\end{array}$ \\
\hline Village has pucca road & $\begin{array}{l}0.006 \\
(0.05)\end{array}$ & $\begin{array}{c}0 \\
(0.01)\end{array}$ & $\begin{array}{l}0.075 \\
(1.32)\end{array}$ & $\begin{array}{l}0.027 \\
(0.47)\end{array}$ & $\begin{array}{l}-0.084 \\
(1.61)\end{array}$ & $\begin{array}{l}-0.039 \\
(0.65)\end{array}$ & $\begin{array}{l}0.043 \\
(0.81)\end{array}$ & $\begin{array}{l}-0.056 \\
(1.05)\end{array}$ \\
\hline Village has electricity & $\begin{array}{l}-0.151 \\
(0.84)\end{array}$ & $\begin{array}{l}-0.041 \\
(0.51)\end{array}$ & $\begin{array}{l}-0.104 \\
(1.18)\end{array}$ & $\begin{array}{l}-0.087 \\
(0.97)\end{array}$ & $\begin{array}{l}-0.086 \\
(1.08)\end{array}$ & $\begin{array}{l}-0.042 \\
(0.46)\end{array}$ & $\begin{array}{c}-0.372 \\
(4.46)^{* *}\end{array}$ & $\begin{array}{l}-0.038 \\
(0.46)\end{array}$ \\
\hline \# of mosques in the village & $\begin{array}{l}-0.038 \\
(1.12)\end{array}$ & $\begin{array}{c}-0.051 \\
(2.60)^{* *}\end{array}$ & $\begin{array}{l}-0.025 \\
(1.22)\end{array}$ & $\begin{array}{l}-0.039 \\
(1.80)+\end{array}$ & $\begin{array}{l}0.018 \\
(0.93)\end{array}$ & $\begin{array}{c}0.055 \\
(2.43)^{*}\end{array}$ & $\begin{array}{c}0.062 \\
(3.27)^{* *}\end{array}$ & $\begin{array}{c}-0.061 \\
(3.14)^{* *}\end{array}$ \\
\hline Village semi urban & $\begin{array}{l}-0.317 \\
(2.36)^{*}\end{array}$ & $\begin{array}{c}0.402 \\
(4.69)^{* *}\end{array}$ & $\begin{array}{c}0.469 \\
(5.18)^{* *}\end{array}$ & $\begin{array}{c}0.398 \\
(4.33)^{* *}\end{array}$ & $\begin{array}{l}-0.005 \\
(0.06)\end{array}$ & $\begin{array}{l}0.076 \\
(0.75)\end{array}$ & $\begin{array}{c}-0.539 \\
(6.35)^{* *}\end{array}$ & $\begin{array}{l}-0.073 \\
(0.87)\end{array}$ \\
\hline Village economic inequality & $\begin{array}{c}0.002 \\
(2.12)^{*}\end{array}$ & $\begin{array}{c}0 \\
(0.61)\end{array}$ & $\begin{array}{c}0 \\
(0.28)\end{array}$ & $\begin{array}{c}0 \\
(0.31)\end{array}$ & $\begin{array}{l}0.001 \\
(1.07)\end{array}$ & $\begin{array}{l}0.001 \\
(1.03)\end{array}$ & $\begin{array}{c}-0.003 \\
(4.86)^{* *}\end{array}$ & $\begin{array}{c}0 \\
(0.42)\end{array}$ \\
\hline Village has NGO presence & $\begin{array}{c}0.05 \\
(0.46)\end{array}$ & $\begin{array}{l}-0.131 \\
(2.39)^{*}\end{array}$ & $\begin{array}{c}-0.072 \\
(1.22)\end{array}$ & $\begin{array}{l}-0.125 \\
(2.09)^{*}\end{array}$ & $\begin{array}{l}-0.03 \\
(0.56)\end{array}$ & $\begin{array}{c}-0.208 \\
(3.26)^{* *}\end{array}$ & $\begin{array}{l}-0.045 \\
(0.82)\end{array}$ & $\begin{array}{c}0.01 \\
(0.18)\end{array}$ \\
\hline Observations & 2122 & 2068 & 1916 & 1843 & 2015 & 1551 & 2103 & 2013 \\
\hline Pseudo $\mathrm{R}^{2}$ & 0.13 & 0.03 & 0.04 & 0.04 & 0.02 & 0.02 & 0.04 & 0.06 \\
\hline
\end{tabular}




\subsection{Additional robustness checks}

In this section, we put our finding through several robustness tests. First, concerns remain over the manner in whichanswers to trust questions in rural communities vary depending on who asked the question (e.g. female, non-Muslim enumerator and so on). The surveyors avoided overtly religious dresses so that they were not immediately recognizable as member of a particular faith group. Nonetheless, we repeated analysis presented in Table 2 with full control for enumerator fixed-effects. Results confirmed that our earlier conclusions are robust to enumerator effects (see Appendix Table 3).

Second, we control for village level measure of social capital based on aggregated score of responses to the generalized trust question given to respondents during the village population census (results not reported but available from the authors upon request). While for some trust attitude questions, the aggregate measure of trust attitude is significant, in no case it wipes out the effect of institutional trust and the influence of religious affiliation of the respondent. This confirms that the results reported earlier are not driven by the effect of living in high/low trust communities.

Third, we test the hypothesis of "minority status" by looking into sub-region effects. If the observed difference in trust attitudes between Hindu and Muslim communities reflects minority and majority status, respectively, out-group bias should not vary significantly across regions. Our sample contains interior districts, as well as those bordering India, a Hindu majority country. Bordering regions have a greater concentration of Hindus, but at the same time, they are also less developed and are remote to the capital. We therefore split our respondents in two sub-samples containing either only bordering or interior districts, and estimate the relationship 
between trust and religion separately on those two sub-populations (see Appendix Table 4). We find that Hindus trust other Hindus and Muslims less in bordering areas compared to interior regions. This is consistent with the fact that in isolated places, inter-personal trust is low. However, our main results remain unchanged. We find that both Hindus and Muslims in Bangladesh trust others from their own religions more than they trust people from other religions. Moreover, Hindus trust Christians and Buddhists more than Muslims, and are not distrustful of the wider society. This subsample analysis suggests that out-group bias in our data does not necessarily reflect the relative status of the religious group in the population.

Despite extensive controls for various correlates of trust and robustness tests, our model leaves out a number of factors. Members of the minority (e.g. Hindu) community may trust Muslims less owing to have suffered traumatic experience of religious and political violence. But our data set contains no information on the history of such violence in sample villages; we at most control for economic shocks. Equally, the relationship between institutional and social trust can run the other way around as well (Keefer and Knack 1997; Knack 2002; Beugelsdijk, 2006; Bjørnskov and Méon, 2013). We are constrained by the cross-sectional nature of the data to address these issues.

Lastly, madrasa attendance itself may be an outcome of lack of trust in public institutions such as government schools. The negative coefficient on madrasa dummy may be a consequence of selection bias, if distrusting parents are more likely to send their children to religious schools and, as is known, likely to pass their distrust onto $\begin{array}{llll}\text { their } & \text { To enildren. }\end{array}$ we attempted instrumenting the madrasa dummy in a IV-probit model using information on distance to secondary schools and madrasas when the respondent was 
15 years old. However, the exclusion restriction was not satisfied in most cases, perhaps because the experience of being raised in under-provided and isolated communities itself undermined trusting behaviour. In the absence of other variables that we could use for identification purposes, the evidence presented remains descriptive, and not causal.

\section{Conclusion}

In this paper, we have used Bangladesh as a case study and empirically investigated the determinants of inter-personal trust. The measurement of trust is a contentious topic in the social science literature. Therefore, in addition to using the generalized trust question, we have employed questions to directly capture trust towards specific social groups. We find significant social distance among various faith groups Hindus, the minority, trust Muslims more than Muslims trust Hindus. We also find no evidence that Hindus are distrustful of the wider society, and of other non-Hindus in general. If anything, they trust non-Muslims of all denominations and NGO workers more compared to Muslims. These findings do not proxy for between religion differences in institutional trust. This is despite the fact that perceived institutional trust increases inter-personal trust in our data. Among Muslim respondents, the lack of trust towards Hindus and other non-Muslims is significantly and positively correlated with Islamic school attendance, while religiosity appears to play no role in this case. These findings are robust to control for a wide range of individual and community level correlates and enumerator fixed effects. Altogether, our results suggest that mistrust between Bangladesh’s two main religious communities, Muslims and Hindus, limits the scope for creating social capital in rural areas.

Nonetheless, we have highlighted two policy channels for fostering interpersonal trust. First, the significant association between institutional trust and social 
trust suggests that policy reforms that reduce corruption may improve interpersonaltrust via increasing institutional trust in rural Bangladesh. Here policy measures against corruption such as social campaigns using the media and school curriculum reform to instil moral values can be effective (Narayan 2002). Second, while we found no effect of years of schooling, madrasa attendance was negatively correlated with level of trust towards minority religious groups. If the madrasa effect is causal, this suggests that social trust can be fostered through appropriate educational reform programs. Curriculum reform targeting Islamic schools can improve generalized trust attitude among one segment of the Muslim population in Bangladesh. ${ }^{28}$ Our study thus lends some support to the view that social trust in low income countries can be built through a combination of institutional and policy reforms.

It should be noted that the between-group difference in trust attitude documented in our paper could be also shaped by historical experience rather than the theology of respective religious groups. Only a small proportion of Bangladeshi Muslims attend Islamic schools (Asadullah and Chaudhury 2016) and we do not find a direct role of religiosity among Muslims on trust attitudes. This highlights the possibility that the role of religion in inculcating a trusting attitude can be ambiguous. The between-group trust attitude can be driven by the actual experience of people rather than the theology of the particular religions. If so, legal and institutional reforms protecting minority rights and livelihoods can also play an important role.

Lastly, some researchers have cautioned against the etic approach when studying trust across respondents of different countries/cultures (e.g. Zaheer and Zaheer, 2006; Bachmann and Zaheer 2013). In our study, the main focus is between (religious) group differences in trust, where respondents are drawn from rural

\footnotetext{
${ }^{28}$ Indeed Asadullah (2016) find that students enrolled in state recognized secondary level Islamic schools in rural Bangladesh have systematically higher generalized trust score compared to their peers from unrecognized, traditional madrasas.
} 
Bangladesh. However, if the basic features of trust in Bangladeshi society are emic, then trust Muslims have in other Muslims may not be in the same form as the trust they have in non-Muslims. It may not be possible to build Hindu-Muslim trust using the same mechanism that promotes trust among Muslims. Future studies should combine etic and emic approaches to study the determinants of trust in Bangladesh. 


\section{Reference}

Ahmed, A. M. (2009) “Are Religious People More Prosocial?” Journal for the Scientific Study of Religion, 2009, 48(2), 368-374.

Ahmed, A. M. and Osvaldo Salas (2009) "The relationship between behavioral and attitudinal trust: a cross-cultural study”, Review of Social Economy, 67(4), 457-482.

Alesina, A. and La Ferrara, E. (2002) "Who trusts others?," Journal of Public Economics, 85(2), 207-234.

Algan, Yann and Pierre Cahuc (2010) "Inherited Trust and Growth," American Economic Review, 2010, vol. 100, issue 5, pages 2060-92.

Aghion, P., Algan, Y., Cahuc, P. and Shleifer, A. (2010) "Regulation and Distrust," Quarterly Journal of Economics, 125(3): 1015-1049.

Anderson, L. R., Mellor, J., and Milyo, J. (2010) "Did the Devil Make Them Do It? The Effects of Religion in Public Goods and Trust Games -super”, Kyklos, 63(2), 163-175.

Arbel, Y., Bar-El, Ronen, S., E. and Tobol, Y. (2014) “The Effect of Behavioral Codes and Gender on Honesty”, IZA working paper 7946.

Asadullah, M. Niaz (2016) Trust, Trustworthiness, and Traditional Islamic Education, Oxford Development Studies, vol. 44(2), 152-166.

Asadullah, M Niaz, Savoia, Antonio and Mahmud, Wahiduddin (2014) "Paths to Development: Is There a Bangladesh Surprise?" World Development, 62, 138-154.

Asadullah, M Niaz and Chaudhury, Nazmul (2016) "To Madrasahs or Not to Madrasahs: The Question and Correlates of Enrolment in Islamic Schools in Bangladesh", International Journal of Educational Development, (49), 55-69.

Bachmann, R. (2001) “Trust, power and control in trans-organizational relations.” Organization Studies, 22, 337-365.

Bachmann, R and Inkpen, AC (2011) "Understanding institutional-based trust building processes in inter-organizational relationships," Organization Studies, 32 (2). pp. 281-301.

Bachmann, R. and Zaheer, A. (2013) Handbook of Advances in Trust Research. Cheltenham: Edward Elgar.

Berggren, Niclas and Bjørnskov, Christian (2011) "Is the importance of religion in daily life related to social trust? Cross-country and cross-state comparisons", Journal of Economic Behavior and Organization, 80(3), 459-480. 
Ben-Ner, Avner and Halldorsson, Freyr (2010) “Trusting and trustworthiness: What are they, how to measure them, and what affects them", Journal of Economic Psychology 31(1), 64-79.

Berman, Eli (2000) "Sect, Subsidy, and Sacrifice: An Economist's View of UltraOrthodox Jews,” Quarterly Journal of Economics, 115(3), 905-953.

Beugelsdijk, S (2006) "A note on the theory and measurement of trust in explaining differences in economic growth”, Cambridge Journal of Economics, 30, 371-87.

Bohnet, Iris and Baytelman, Yael (2007) "Institutions and Trust: Implications for Preferences, Beliefs and Behavior”, Rationality and Society, vol. 19(1), pp. 99-135.

Brañas-Garza, Pablo, Rossi, Maximo and Zaclicever, Dayna (2009) "Individual's Religiosity Enhances Trust: Latin American Evidence for the Puzzle”, Journal of Money, Credit and Banking, 41(2-3), 555-566.

Brañas-Garza, P., Espín, A. M., and Neuman, S. (2013). Effects of religiosity on social behaviour: Experimental evidence from a representative sample of Spaniards (No. 7683). IZA Discussion Paper.

Bidner, Chris and Patrick Francois (2011) "Cultivating Trust: Norms, Institutions and the Implications of Scale,” Economic Journal, 121(555), 1097-1129.

Bjørnskov, Christian (2003) "The happy few: Cross-country evidence on social capital and life satisfaction,” Kyklos, 56, 3-16.

Bjørnskov, Christian (2007) "Determinants of generalized trust: A cross-country comparison,” Public Choice, 130(1), 1-21.

Bjørnskov, Christian (2009) "Social trust and the growth of schooling," Economics of Education Review, 28(2), 249-257.

Bjørnskov, Christian and Méon, Pierre-Guillaume (2013) "Is Trust the Missing Root of Institutions, Education, and Development?” Public Choice, 157(3), 641-669.

Bulloch, Sarah (2013) "Seeking Construct Validity in Interpersonal Trust Research: A Proposal on Linking Theory and Survey Measures," Social Indicators Research, 113(3), 1289-1310.

Cardenas, J. and Carpenter, J. (2008) "Behavioural Development Economics: Lessons from Field Labs in the Developing World," The Journal of Development Studies, 44(3), 311-338.

Charles, Robia (2010) "Religiosity and Trust in Religious Institutions: Tales from the South Caucasus (Armenia, Azerbaijan, and Georgia)," Politics and Religion, 3, 228261.

Coleman, J.S. (1990). Foundations of social theory. Cambridge, MA: Harvard University Press. 
Chuah, S., Fahoum, R. and Hoffmann, R. (2013) "Fractionalization and trust in India: A field-experiment” Economics Letters, 119(2), 191-194.

Daniels, Joseph and von der Ruhr, Marc (2010) "Trust in Others: Does Religion Matter?," Review of Social Economy, 68(2), 163-186.

Dearmon, J. and Grier, K., (2009), “Trust and development,” Journal of Economic Behavior \& Organization, 71(2), 210-220.

Delavande, A. and Zafar, B. (2015) "Stereotypes and Madrassas: Experimental evidence from Pakistan,” Journal of Economic Behavior and Organization, 118, 247267.

Delhey, J., and Newton, K. (2003) "Who trusts?: The origins of social trust in seven societies,” European Societies, 5(2), 93-137.

Delhey, J., Newton, K., \& Welzel, C. (2011) "How General Is Trust in "Most People? Solving the Radius of Trust Problem,” American Sociological Review, 76(5), 786807.

D’Hernoncourt, J. and Méon, Pierre-Guillaume (2012) "The not so dark side of trust: Does trust increase the size of the shadow economy?," Journal of Economic Behavior and Organization, 81(1), 97-121.

Dixit, Avinash K. (2004) Lawlessness and Economics: Alternative Modes of Governance. Princeton, NJ and Oxford, UK: Princeton University Press.

Etang, Alvin, David Fielding and Stephen Knowles (2012) "Are Survey Measures of Trust Correlated with Experimental Trust? Evidence from Cameroon," in Journal of Development Studies, vol. 48, issue 12, pages 1813-1827.

Ferrin D. L. and Gillespie N. (2010) "Trust differences across national-societal cultures: Much to do, or much ado about nothing?” In Saunders M. N.

K., Skinner D., Dietz G.,Gillespie N., Lewicki R. J. (Eds.), Organizational trust: A cultural perspective:42-86.New York: Cambridge University Press.

Fulmer, C. Ashley and Gelfand, Michele J. (2012) "At What Level (and in Whom) We Trust: Trust Across Multiple Organizational Levels,” Journal of Management, vol. 38 no. 4 1167-1230.

Fehr, Ernst (2009) “On the economics and biology of trust”, Journal of the European Economic Association, 7(2-3), 235-266.

Freitag, Markus and Traunmüller, Richard (2009) “Spheres of Trust”, European Journal of Political Research, Vol 48(6), pp 782-803.

Glaeser, E. G., Laibson, D., Scheinkman, J. A., and Soutter, C. L. (2000). “Measuring Trust," Quarterly Journal of Economics 65, 811-846. 
Guiso, L. and Sapienza, P. \& Zingales, L. (2003) "People's opium? Religion and economic attitudes,” Journal of Monetary Economics, 50(1), 225-282.

Guiso, L., P. Sapienza and L. Zingales (2008) "Social Capital as Good Culture,” Journal of the European Economic Association, 6(2-3): 295-320.

Güth, W., Levati, M. V., and Ploner, M. (2008) "Social identity and trust: An experimental investigation”, The Journal of Socio-Economics, 37(4), 1293-1308.

Güth, W., Ploner, M., \& Regner, T. (2009) “Determinants of in-group bias: Is group affiliation mediated by guilt-aversion?” Journal of Economic Psychology, 30(5), 814827.

Haddad, L., and Maluccio, J. A. (2003) "Trust, Membership in Groups, and Household Welfare: Evidence from KwaZulu-Natal, South Africa”, Economic Development and Cultural Change, 51(3), 573-601.

Henrich, J., Ensminger, J., McElreath, R., Barr, A., Barrett, C., Bolyanatz, A., et al (2010) "Markets, religion, community size, and the evolution of fairness and punishment," Science, 327, 1480-1484.

Holm, H. J., and Danielson, A. (2005) "Tropic trust versus Nordic trust: Experimental evidence from Tanzania and Sweden", The Economic Journal, 115(503), 505-532.

Horváth, Roman (2013) "Does trust promote growth?," Journal of Comparative Economics, 41(3), 777-788.

Johansson-Stenman, O., Mahmud, M. and Martinsson, P. (2009) "Trust and Religion: Experimental Evidence from Rural Bangladesh,” Economica, 76(303), 462-485.

Johnson, Noel and Mislin, A. (2012) "How Much Should We Trust the World Values Survey Trust Question?,” Economics Letters, 116(2), 210-212.

Kabeer, N. and Matin, Imran (2005) “The wider social impacts of BRAC's groupbased lending in rural Bangladesh: Group dynamics and participation in public life”, BRAC research monograph no. 25.

Knack, S. (2002) "Social capital and the quality of government: Evidence from the States,” American Journal of Political Science, 772-785.

Knack, S., and P. Keefer (1997) "Does social capital have an economic pay-off? A cross-country investigation,” Quarterly Journal of Economics, 112, 1251-1288.

Knack, S. and Zak, P (2003) "Building Trust: Public Policy, Interpersonal Trust, and Economic Development,” Supreme Court Economic Review, 91-107. 
Keefer, P., and Knack, S. (1997) "Why Don't Poor Countries Catch Up? A Cross-National Test of an Institutional Explanation,” Economic Inquiry, 35(3), 590602.

Knox, Colin (2009) "Building Trust amidst Corruption in Bangladesh,” The Round Table: The Commonwealth Journal of International Affairs, 98:403, 449-459.

Leigh, Andrew (2006) “Trust, Inequality, and Ethnic Heterogeneity," Economic Record, 82(258), 268-280.

McKnight, D. Harrison and Chervany, Norman L. (2001) “Trust and Distrust Definitions: One Bite at a Time”. In R. Falcone, M. Singh, and Y.-H. Tan (Eds.): Trust in Cyber-societies, pp. 27-54. Springer-Verlag London, UK.

Mondal, Abdul H (2000) "Social Capital Formation: The Role of NGO Rural Development Programs in Bangladesh" Policy Sciences, 33(3-4), pp 459-475.

Narayan, Deepa (2002) “Bonds and Bridges: Social Capital and Poverty”. In Jonathan Isham, Thomas Kelly and Sunder Ramaswamy (eds) Social Capital and Economic Development: Well-being in Developing Countries. Northampton, MA, Edward Elgar.

Naef, Michael and Schupp, Jürgen (2009) "Measuring Trust: Experiments and Surveys in Contrast and Combination”, No 4087, IZA Discussion Papers Institute for the Study of Labor (IZA) (2009)

Neusner, Jacob and Bruce Chilton (2005) Altruism in world religions. Washington, D.C.: Georgetown University Press.

Obadia, Lionel and Wood, Donald (2011) The Economics of Religion:

Anthropological Approaches (Research in Economic Anthropology, Volume 31. Emerald Group Publishing Limited.

Özcan, Burcu and Bjørnskov, Christian (2011) "Social trust and human development,” The Journal of Socio-Economics, 40(6), 753-762.

Rainer, Helmut and Siedler, Thomas (2009) "Does Democracy Foster Trust?," Journal of Comparative Economics, 37(2), 251-269.

Rothstein, B. (2005) Social Traps and the Problem of Trust, Cambridge, Cambridge University Press.

Rousseau, M. T., S. B., Sitkin, S. B. Burt, \& C. Camerer. (1998) "Not so Different After All: A Cross-Discipline View of Trust,” Academy of Management Review, 23, 393-404.

Sarkissian, Ani (2012) "Religion and Civic Engagement in Muslim Countries," Journal for the Scientific Study of Religion, 51(4), 607-622. 
Saunders M, Skinner D, Gillespie N, Dietz G, and Lewicki R.

(2010) Organisational trust: a cultural perspective. Cambridge: Cambridge

University Press.

Saunders, MNK and Thornhill, A. (2011) "Researching sensitively without sensitizing: Using a card sort in a concurrent mixed methods design to research trust and distrust,” International Journal of Multiple Research Approaches, 5:3, 334-350.

Sapienza, Paola, Toldra-Simats, Anna, and Luigi Zingales (2013) "Understanding Trust,” Economic Journal, 123(12): 1313-1332.

Schneider, F. and D.H. Enste (2000) "Shadow economies: size, causes, and consequences,” Journal of Economic Literature, 38, 77-114.

Smith, A. (2011). Identifying In-Group and Out-Group Effects in the Trust Game. The B.E. Journal of Economic Analysis and Policy: Vol 11: ISS 1 (Topics), Article 38.

Sturgis, Patrick and Smith, Patten (2010) “Assessing the Validity of Generalized Trust Questions: What Kind of Trust are we Measuring?” International Journal of Public Opinion Research, 22 (1): 74-92.

Tabellini, G. (2008) “The scope of cooperation: Values and incentives," The Quarterly Journal of Economics, 123 (3), 905-950.

Tabellini, Guido (2010) "Culture and Institutions: Economic Development in the Regions of Europe,” Journal of the European Economic Association, 8(4), 677-716.

Tan, Jonathan H W and Vogel, Claudia (2008) "Religion and trust: An experimental study,” Journal of Economic Psychology, 29(6), 832-848.

Thöni, Christian and Tyran, Jean-Robert and Wengström, Erik (2012)

“Microfoundations of social capital,” Journal of Public Economics, 96(7-8), 635-643.

Tu, Qin and Bulte, Erwin (2010) “Trust, Market Participation and Economic Outcomes: Evidence from Rural China,” World Development, 38(8), 1179-1190.

Tsutsui, Kei and Zizzo, Daniel (2014) “Group status, minorities and trust”, in Experimental Economics (2014), vol. 17, issue 2, pages 215-244.

Uslaner, E. M. (2002) The Moral Foundations of Trust, New York, Cambridge University Press

Uslaner, E. M. (2008a), "The foundations of trust: Macro and micro" Cambridge Journal of Economics, 32(2):289-294.

Uslaner, E.M. (2008b) The Bulging Pocket and the Rule of Law: Corruption, inequality, and the rule of law. Cambridge University Press, New York. 
Uslaner, E. M. (2013) “Trust and corruption revisited: how and why trust and corruption shape each other”, Quality and Quantity, 47(6) pp 3603-3608.

Wang, Lanlan and Gordon, Peter (2011) "Trust and institutions: A multilevel analysis,” Journal of Socio-Economics, 40(5), 583-593.

Welch, Michael R., Sikkink, David and Loveland, Matthew T. (2007) "The Radius of Trust: Religion, Social Embeddedness and Trust in Strangers,” Social Forces, 86(1), 23-46.

Williams, M. (2001) "In whom we trust: Group membership as an affective context for trust development,” Academy of Management Review, 26(3), 377-396.

Zaheer, Srilata and Zaheer, Akbar (2006) "Trust across borders", Journal of International Business Studies, 37, 21-29.

Zak, Paul J. and Knack, Stephen (2001) “Trust and Growth,” Economic Journal, 111(470), 295-321.

Whaley, AL. and Longoria, RA. (2009) "Preparing card sort data for multidimensional scaling analysis in social psychological research: a methodological approach," Journal of Social Psychology, 149(1):105-15. 
Appendix Table 1: Division-wise breakdown of responses to trust questions

\begin{tabular}{|c|c|c|c|c|c|c|c|c|c|c|c|c|}
\hline \multirow[b]{2}{*}{ Variable } & \multicolumn{2}{|l|}{ Barisal } & \multicolumn{2}{|l|}{ Khulna } & \multicolumn{2}{|c|}{ Rajshashi } & \multicolumn{2}{|c|}{ Chittagong } & \multicolumn{2}{|l|}{ Sylhet } & \multicolumn{2}{|c|}{ Dhaka } \\
\hline & Mean & & Mean & & Mean & & Mean & & Mean & & Mean & \\
\hline Trust Hindu? & 2.57 & $(1.46)$ & 2.86 & $(1.55)$ & 2.90 & (1.43) & 2.50 & (1.53) & 2.57 & $(1.54)$ & 2.53 & $(1.51)$ \\
\hline Trust Christians? & 2.34 & $(1.47)$ & 2.81 & $(1.51)$ & 2.64 & $(1.37)$ & 2.10 & $(1.38)$ & 2.50 & (1.53) & 2.11 & $(1.43)$ \\
\hline Trust Buddhist? & 2.14 & (1.39) & 2.72 & $(1.54)$ & 2.70 & (1.38) & 2.12 & (1.39) & 2.55 & $(1.51)$ & 2.12 & (1.39) \\
\hline Trust strangers? & 3.21 & $(1.42)$ & 3.20 & $(1.22)$ & 3.24 & $(1.16)$ & 3.16 & $(1.30)$ & 3.18 & $(1.21)$ & 3.23 & $(1.46)$ \\
\hline Trust foreigner? & 2.85 & $(1.40)$ & 2.98 & $(1.40)$ & 2.69 & (1.33) & 2.41 & $(1.42)$ & 2.68 & $(1.28)$ & 2.54 & (1.57) \\
\hline Trust generally? & 3.45 & (1.39) & 1.59 & $(0.98)$ & 3.99 & $(1.40)$ & 3.75 & $(1.40)$ & 3.10 & (1.43) & 3.32 & (1.31) \\
\hline Happiness & 6.12 & $(2.70)$ & 5.20 & $(1.72)$ & 6.06 & (2.65) & 5.23 & $(2.03)$ & 6.26 & $(2.34)$ & 5.34 & (2.49) \\
\hline Observations & 199 & & 200 & & 400 & & 799 & & 400 & & 400 & \\
\hline
\end{tabular}

Note: Standard deviation in parenthesis.

\section{Appendix Table 2: Descriptive statistics}

\begin{tabular}{|c|c|c|c|c|c|c|}
\hline \multirow{3}{*}{$\begin{array}{l}\text { Variable } \\
\text { Individual characteristics }\end{array}$} & \multirow{2}{*}{$\begin{array}{c}\begin{array}{c}\text { Full } \\
\text { sample }\end{array} \\
\text { Mean } \\
\end{array}$} & \multicolumn{3}{|c|}{ Muslim } & \multicolumn{2}{|c|}{ Hindu } \\
\hline & & \multicolumn{2}{|l|}{ Std. } & $\begin{array}{c}\text { Std. } \\
\text { Dev. }\end{array}$ & Mean & Std. Dev. \\
\hline & & & & & & \\
\hline Female & 0.17 & 0.37 & 0.17 & 0.38 & 0.12 & 0.32 \\
\hline Hindu & 0.08 & 0.27 & & & 1 & 0 \\
\hline Married & 0.92 & 0.28 & 0.92 & 0.28 & 0.92 & 0.27 \\
\hline Age & 45.58 & 10.43 & 45.58 & 10.49 & 45.56 & 9.78 \\
\hline Head has no education & 0.48 & 0.50 & 0.49 & 0.50 & 0.32 & 0.47 \\
\hline Confidence index (non-religious institutions) & 21.30 & 4.76 & 20.33 & 4.71 & 20.30 & 4.76 \\
\hline Confidence index (religious institutions) & 5.31 & 1.75 & 6.21 & 1.58 & 5.31 & 1.75 \\
\hline \multicolumn{7}{|l|}{ Household characteristics } \\
\hline Per capita monthly expenditure & 2101.85 & 1053.91 & 2083.38 & 1046.32 & 2312.93 & 1118.35 \\
\hline House wall made of mud & 0.38 & 0.49 & 0.38 & 0.48 & 0.45 & 0.50 \\
\hline No economic shock & 0.38 & 0.49 & 0.38 & 0.49 & 0.41 & 0.49 \\
\hline Wealth relative to others & 2.56 & 1.05 & 2.58 & 1.05 & 2.39 & 1.03 \\
\hline \multicolumn{7}{|l|}{ Village characteristics } \\
\hline$\overline{\text { Village has non-Muslims }}$ & 0.08 & 0.12 & 0.06 & 0.10 & 0.25 & 0.16 \\
\hline Village has pucca road & 0.59 & 0.49 & 0.59 & 0.49 & 0.49 & 0.50 \\
\hline Village has electricity & 0.89 & 0.32 & & & & \\
\hline \# of mosques in the village & 2.29 & 1.48 & 2.34 & 1.49 & 1.77 & 1.18 \\
\hline Village semi urban & 0.10 & 0.31 & 0.11 & 0.31 & 0.09 & 0.29 \\
\hline Village economic inequality & 115.96 & 50.65 & 116.19 & 50.42 & 113.32 & 53.32 \\
\hline Village average GSS score & 3.46 & 0.70 & 3.44 & 0.71 & 3.62 & 0.55 \\
\hline Observations & 2393 & & 2200 & & 193 & \\
\hline
\end{tabular}

Note: (a) "Confidence index (non-religious institutions)" is calculated over seven domains and has a theoretical range of 7 (no confidence at all) and 28 (full confidence). (b) "Confidence index (religious institutions)" is calculated over two domains, religious institutions and religion based political party, and hence has a theoretical range of 2 (no confidence at all) and 8 (full confidence). 
Appendix Table 3: Ordered Probit estimates of determinants of social trust with enumerator fixed-effects

\begin{tabular}{|c|c|c|c|c|c|c|c|c|}
\hline & Trust Muslim? & Trust Hindu? & Trust Christian? & Trust Buddhist? & Trust strangers? & Trust foreigners? & Trust people in general? & Trust NGO worker? \\
\hline \multirow{2}{*}{ Female } & -0.09 & -0.172 & -0.212 & -0.229 & 0.132 & -0.144 & -0.047 & 0.001 \\
\hline & $(0.56)$ & $(2.06)^{*}$ & $(2.40)^{*}$ & $(2.51)^{*}$ & $(1.65)^{+}$ & $(1.48)$ & $(0.57)$ & $(0.01)$ \\
\hline \multirow[t]{2}{*}{ Hindu } & -2.073 & 2.283 & 1.054 & 1.162 & 0.05 & 0.159 & -0.193 & 0.264 \\
\hline & $(14.92)^{* *}$ & $(18.93)^{* *}$ & $(9.89)^{* *}$ & $(10.80)^{* *}$ & $(0.51)$ & (1.43) & $(0.98)$ & $(2.53)^{*}$ \\
\hline \multirow[t]{2}{*}{ Married } & -0.348 & -0.086 & -0.216 & -0.167 & -0.123 & -0.23 & 0.017 & -0.046 \\
\hline & $(1.65)^{+}$ & $(0.82)$ & $(1.96)^{*}$ & $(1.47)$ & $(1.24)$ & $(1.92)^{+}$ & $(0.16)$ & $(0.45)$ \\
\hline \multirow[t]{2}{*}{ Age } & 0.032 & 0.012 & 0.015 & 0.001 & 0.006 & 0 & 0.033 & 0.021 \\
\hline & $(1.16)$ & $(0.81)$ & $(0.96)$ & $(0.06)$ & $(0.45)$ & $(0.02)$ & $(2.27)^{*}$ & (1.46) \\
\hline \multirow[t]{2}{*}{ No education } & 0.221 & 0.025 & -0.011 & -0.026 & 0.119 & 0.021 & 0.079 & 0.099 \\
\hline & $(2.19)^{*}$ & $(0.46)$ & $(0.19)$ & $(0.44)$ & $(2.28)^{*}$ & $(0.34)$ & (1.46) & $(1.86)^{+}$ \\
\hline \multirow[t]{2}{*}{ Log of per capita household expenditure } & 0.017 & 0.076 & 0.151 & 0.145 & 0.101 & 0.179 & -0.04 & -0.175 \\
\hline & $(0.13)$ & (1.09) & $(2.03)^{*}$ & $(1.90)^{+}$ & (1.48) & $(2.21)^{*}$ & $(0.57)$ & $(2.52)^{*}$ \\
\hline \multirow[t]{2}{*}{ House wall made of mud } & 0.099 & 0.032 & 0.062 & 0.062 & 0.02 & 0.125 & -0.009 & 0.091 \\
\hline & $(0.91)$ & $(0.54)$ & $(1.03)$ & $(0.99)$ & $(0.35)$ & $(1.88)^{+}$ & $(0.15)$ & $(1.57)$ \\
\hline \multirow[t]{2}{*}{ No economic shock } & -0.02 & 0.155 & 0.159 & 0.203 & 0.036 & -0.068 & -0.03 & 0.009 \\
\hline & $(0.22)$ & $(2.82)^{* *}$ & $(2.76)^{* *}$ & $(3.49)^{* *}$ & $(0.68)$ & $(1.08)$ & $(0.54)$ & $(0.17)$ \\
\hline \multirow[t]{2}{*}{ Confidence index } & 0.048 & 0.035 & 0.039 & 0.043 & 0.048 & 0.062 & 0.016 & 0.095 \\
\hline & $(4.42)^{* *}$ & $(5.87)^{* *}$ & $(6.01)^{* *}$ & $(6.46)^{* *}$ & $(8.22)^{* *}$ & $(8.82)^{* *}$ & $(2.67)^{* *}$ & $(15.45)^{* *}$ \\
\hline \multirow{2}{*}{ Wealth relative to others } & 0.09 & 0.017 & 0.052 & 0.063 & -0.001 & 0.009 & -0.009 & -0.02 \\
\hline & $(1.75)^{+}$ & $(0.61)$ & $(1.79)^{+}$ & $(2.12)^{*}$ & $(0.02)$ & $(0.32)$ & $(0.34)$ & $(0.73)$ \\
\hline \multirow[t]{2}{*}{ Village has non-Muslims } & -0.464 & 0.266 & -0.14 & -0.057 & -0.382 & -0.157 & -0.442 & -0.287 \\
\hline & $(0.99)$ & $(0.91)$ & $(0.45)$ & $(0.18)$ & $(1.34)$ & $(0.47)$ & (1.52) & (1.09) \\
\hline \multirow[t]{2}{*}{ Village has puсca road } & 0.173 & 0.01 & 0.075 & 0.046 & -0.052 & 0.042 & -0.051 & -0.061 \\
\hline & (1.53) & $(0.18)$ & (1.23) & $(0.74)$ & $(0.93)$ & $(0.66)$ & $(0.86)$ & $(1.07)$ \\
\hline \multirow[t]{2}{*}{ Village has electricity } & -0.125 & 0.097 & 0.029 & 0.084 & 0.052 & 0.205 & -0.039 & 0.023 \\
\hline & $(0.71)$ & $(1.12)$ & $(0.32)$ & $(0.91)$ & $(0.63)$ & $(2.15)^{*}$ & $(0.44)$ & $(0.27)$ \\
\hline \multirow[t]{2}{*}{ \# of mosques in the village } & -0.039 & -0.044 & -0.019 & -0.037 & -0.028 & 0.001 & -0.06 & -0.027 \\
\hline & $(1.04)$ & $(1.79)^{+}$ & $(0.71)$ & (1.39) & $(1.16)$ & $(0.02)$ & $(2.48)^{*}$ & (1.12) \\
\hline \multirow[t]{2}{*}{ Village semi urban } & -0.177 & 0.38 & 0.352 & 0.362 & 0.141 & 0.039 & -0.103 & -0.056 \\
\hline & $(1.21)$ & $(4.03)^{* *}$ & $(3.62)^{* *}$ & $(3.63)^{* *}$ & $(1.54)$ & $(0.35)$ & (1.12) & $(0.62)$ \\
\hline \multirow[t]{2}{*}{ Village economic inequality } & 0.001 & 0.001 & 0.001 & 0.001 & 0.001 & 0 & 0 & -0.001 \\
\hline & $(0.76)$ & $(1.73)^{+}$ & $(1.80)^{+}$ & $(1.78)^{+}$ & $(0.72)$ & $(0.34)$ & $(0.53)$ & $(0.95)$ \\
\hline \multirow[t]{2}{*}{ Village has NGO presence } & 0.07 & -0.08 & -0.039 & -0.07 & 0.003 & -0.191 & 0.019 & -0.064 \\
\hline & $(0.66)$ & (1.38) & $(0.64)$ & (1.14) & $(0.05)$ & $(2.86)^{* *}$ & $(0.32)$ & (1.14) \\
\hline Observations & 2309 & 2256 & 2081 & 2009 & 2187 & 1686 & 2291 & 2175 \\
\hline Pseudo $\mathrm{R}^{2}$ & 0.34 & 0.18 & 0.14 & 0.16 & 0.13 & 0.15 & 0.20 & 0.15 \\
\hline
\end{tabular}

Note: See table 2 
Appendix Table 4: Ordered Probit estimates of determinants of social trust: bordering vs. interior sub-districts

\begin{tabular}{|c|c|c|c|c|c|c|c|c|}
\hline & \multicolumn{2}{|c|}{ Trust Muslim? } & \multicolumn{2}{|c|}{ Trust Hindu? } & \multicolumn{2}{|c|}{ Trust Christian? } & \multicolumn{2}{|c|}{ Trust Buddhist? } \\
\hline & Border & Interior & Border & Interior & Border & Interior & Border & Interior \\
\hline \multirow[t]{2}{*}{ Female } & 0.256 & -0.086 & 0.118 & -0.179 & 0.124 & -0.226 & 0.031 & -0.249 \\
\hline & $(0.61)$ & $(0.55)$ & $(0.62)$ & $(2.03)^{*}$ & (0.63) & $(2.42)^{*}$ & $(0.16)$ & $(2.58)^{* *}$ \\
\hline \multirow[t]{2}{*}{ Hindu } & -1.456 & -1.967 & 2.011 & 2.223 & 1.183 & 1.09 & 1.327 & 1.15 \\
\hline & $(4.21)^{* *}$ & $(14.34)^{* *}$ & $(7.64)^{* *}$ & $(17.33)^{* *}$ & $(5.43)^{* *}$ & $(9.40)^{* *}$ & $(5.92)^{* *}$ & $(9.88)^{* *}$ \\
\hline \multirow[t]{2}{*}{ Married } & 0.202 & -0.357 & 0.16 & -0.101 & 0.055 & -0.196 & 0.008 & -0.12 \\
\hline & $(0.46)$ & $(1.65)+$ & (0.73) & (0.89) & $(0.25)$ & (1.62) & $(0.04)$ & (0.95) \\
\hline Age & $(0.31)$ & (0.49) & $(1.80)+$ & $(0.41)$ & $(0.92)$ & (1.05) & (0.93) & $(0.28)$ \\
\hline \multirow[t]{2}{*}{ No education } & 0.305 & 0.276 & 0.044 & 0.006 & 0.12 & -0.068 & 0.08 & -0.083 \\
\hline & (1.14) & $(2.76)^{* *}$ & $(0.37)$ & $(0.11)$ & (1.10) & $(1.08)$ & $(0.66)$ & (1.31) \\
\hline \multirow[t]{2}{*}{ Log of per capita hh expenditure } & -0.071 & 0.268 & -0.329 & 0.107 & -0.307 & 0.178 & -0.291 & 0.169 \\
\hline & $(0.22)$ & $(2.18)^{*}$ & $(2.11)^{*}$ & (1.51) & $(1.86)+$ & $(2.34)^{*}$ & $(1.76)+$ & $(2.17)^{*}$ \\
\hline \multirow[t]{2}{*}{ House wall made of mud } & 0.384 & 0.237 & 0.112 & -0.028 & 0.166 & 0 & 0.135 & 0.018 \\
\hline & $(1.47)$ & $(2.09)^{*}$ & $(0.95)$ & $(0.42)$ & (1.33) & $(0.01)$ & $(1.08)$ & $(0.25)$ \\
\hline No economic shock & 0.38 & 0.011 & 0.049 & 0.086 & 0.139 & 0.098 & 0.17 & 0.132 \\
\hline \multirow{2}{*}{ Confidence index } & 0.072 & 0.052 & 0.09 & 0.027 & 0.081 & 0.037 & 0.081 & 0.037 \\
\hline & $(2.69)^{* *}$ & $(5.77)^{* *}$ & $(7.55)^{* *}$ & $(5.12)^{* *}$ & $(6.69) * *$ & $(6.48)^{* *}$ & $(6.71)^{* *}$ & $(6.14)^{* *}$ \\
\hline \multirow[t]{2}{*}{ Wealth relative to others } & 0.158 & 0.03 & 0.119 & -0.026 & 0.167 & 0.007 & 0.169 & 0.024 \\
\hline & $(1.36)$ & $(0.61)$ & $(2.17)^{*}$ & $(0.87)$ & $(2.99) * *$ & $(0.23)$ & $(3.01)^{* *}$ & $(0.75)$ \\
\hline \multirow[t]{2}{*}{ Village has non-Muslims } & 3.03 & -0.701 & -1.417 & 0.369 & -2.104 & 0.169 & -1.303 & 0.293 \\
\hline & (1.19) & $(1.52)$ & $(1.22)$ & (1.16) & $(1.78)+$ & $(0.52)$ & (1.11) & $(0.88)$ \\
\hline \multirow[t]{2}{*}{ Village has pucca road } & 0.133 & 0.184 & 0.056 & -0.047 & 0.089 & 0.072 & 0.076 & 0.043 \\
\hline & $(0.48)$ & $(1.44)$ & $(0.41)$ & $(0.68)$ & $(0.62)$ & $(0.98)$ & $(0.53)$ & $(0.57)$ \\
\hline \multirow[t]{2}{*}{ Village has electricity } & -0.298 & -0.089 & -0.103 & 0.128 & -0.063 & 0.028 & -0.011 & 0.083 \\
\hline & $(0.69)$ & $(0.47)$ & $(0.47)$ & (1.33) & $(0.29)$ & $(0.27)$ & $(0.05)$ & $(0.79)$ \\
\hline \multirow[t]{2}{*}{ \# of mosques in the village } & 0.253 & -0.06 & -0.072 & -0.02 & -0.068 & 0.018 & 0.037 & 0.002 \\
\hline & $(0.79)$ & $(1.67)+$ & $(0.46)$ & $(0.81)$ & $(0.41)$ & $(0.68)$ & $(0.22)$ & $(0.06)$ \\
\hline \multirow[t]{2}{*}{ Village semi urban } & -0.421 & -0.272 & 0.432 & 0.381 & 0.395 & 0.484 & 0.28 & 0.476 \\
\hline & $(0.82)$ & $(1.76)+$ & $(1.75)+$ & $(3.50)^{* *}$ & (1.63) & $(4.13)^{* *}$ & (1.16) & $(3.95)^{* *}$ \\
\hline \multirow[t]{2}{*}{ Village economic inequality } & -0.002 & 0.001 & 0.001 & 0 & 0 & 0 & 0.001 & -0.001 \\
\hline & $(0.59)$ & $(0.88)$ & $(0.44)$ & $(0.05)$ & $(0.07)$ & $(0.38)$ & $(0.36)$ & $(0.71)$ \\
\hline Village has NGO presence & -0.542 & 0.076 & -0.055 & -0.115 & -0.123 & -0.023 & -0.103 & -0.084 \\
\hline Pseudo $\mathrm{R}^{2}$ & 0.20 & 0.27 & 0.13 & 0.11 & 0.11 & 0.06 & 0.12 & 0.07 \\
\hline
\end{tabular}


Appendix Table 4: Ordered Probit estimates of determinants of social trust: bordering vs. interior sub-districts (continued...)

\begin{tabular}{|c|c|c|c|c|c|c|c|c|}
\hline & \multicolumn{2}{|c|}{ Trust strangers? } & \multicolumn{2}{|c|}{ Trust foreigners? } & \multicolumn{2}{|c|}{$\begin{array}{l}\text { Trust people in } \\
\text { general? }\end{array}$} & \multicolumn{2}{|c|}{ Trust NGO worker? } \\
\hline & Border & Interior & Border & Interior & Border & Interior & Border & Interior \\
\hline \multirow[t]{2}{*}{ Female } & 0.567 & 0.035 & 0.472 & -0.306 & 0.283 & -0.099 & 0.071 & 0.029 \\
\hline & $(3.11)^{* *}$ & $(0.41)$ & $(2.19)^{*}$ & $(2.92)^{* *}$ & (1.48) & (1.14) & (0.38) & $(0.33)$ \\
\hline \multirow[t]{2}{*}{ Hindu } & -0.115 & 0.081 & 0.264 & 0.21 & -0.076 & -0.1 & 0.337 & 0.172 \\
\hline & $(0.57)$ & $(0.77)$ & (1.25) & $(1.70)+$ & $(0.36)$ & $(0.93)$ & $(1.51)$ & (1.53) \\
\hline \multirow[t]{2}{*}{ Married } & 0.126 & -0.163 & 0.363 & -0.361 & -0.016 & 0.058 & -0.281 & 0.051 \\
\hline & $(0.62)$ & (1.49) & (1.53) & $(2.73)^{* *}$ & $(0.07)$ & $(0.52)$ & $(1.24)$ & $(0.45)$ \\
\hline \multirow[t]{2}{*}{ Age } & 0.032 & -0.012 & 0.01 & -0.002 & 0.055 & 0.012 & 0.062 & 0.016 \\
\hline & (1.21) & $(0.79)$ & $(0.32)$ & $(0.11)$ & $(1.93)+$ & $(0.78)$ & $(1.94)^{+}$ & (0.99) \\
\hline \multirow[t]{2}{*}{ No education } & 0.062 & 0.10 & 0.128 & -0.001 & 0.054 & 0.129 & 0.283 & 0.05 \\
\hline & $(0.55)$ & $(1.78)+$ & (1.03) & $(0.01)$ & $(0.45)$ & $(2.24)^{*}$ & $(2.33)^{*}$ & $(0.87)$ \\
\hline \multirow[t]{2}{*}{ Log of per capita hh expenditure } & -0.207 & 0.221 & 0.187 & 0.18 & -0.386 & -0.002 & -0.141 & -0.276 \\
\hline & $(1.37)$ & $(3.19)^{* *}$ & (1.09) & $(2.18)^{*}$ & $(2.40)^{*}$ & $(0.03)$ & $(0.84)$ & $(3.95)^{* *}$ \\
\hline \multirow[t]{2}{*}{ House wall made of mud } & 0.039 & 0.068 & 0.192 & 0.104 & 0.106 & -0.069 & 0.014 & 0.036 \\
\hline & $(0.34)$ & $(1.06)$ & (1.49) & $(1.38)$ & $(0.88)$ & $(1.06)$ & $(0.11)$ & $(0.55)$ \\
\hline \multirow{2}{*}{ No economic shock } & 0.122 & 0.099 & -0.104 & -0.005 & 0.263 & -0.212 & 0.079 & -0.027 \\
\hline & (1.13) & $(1.78)+$ & $(0.86)$ & $(0.08)$ & $(2.30)^{*}$ & $(3.76)^{* *}$ & $(0.69)$ & $(0.48)$ \\
\hline \multirow[t]{2}{*}{ Confidence index } & 0.061 & 0.024 & 0.045 & 0.034 & 0.025 & 0.034 & 0.168 & 0.085 \\
\hline & $(5.49)^{* *}$ & $(4.64)^{* *}$ & $(3.48)^{* *}$ & $(5.32)^{* *}$ & $(2.21)^{*}$ & $(6.47)^{* *}$ & $(12.66)^{* *}$ & $(15.22) * *$ \\
\hline \multirow[t]{2}{*}{ Wealth relative to others } & 0.062 & 0.003 & 0.027 & 0.035 & 0.153 & -0.03 & 0.03 & -0.014 \\
\hline & (1.16) & $(0.12)$ & $(0.45)$ & $(1.07)$ & $(2.70)^{* *}$ & (1.04) & $(0.52)$ & $(0.5)$ \\
\hline \multirow[t]{2}{*}{ Village has non-Muslims } & -0.516 & -0.655 & -2.518 & 0.024 & -0.125 & -0.475 & -0.916 & -0.093 \\
\hline & $(0.48)$ & $(2.15)^{*}$ & $(2.04)^{*}$ & $(0.07)$ & $(0.11)$ & $(1.54)$ & $(0.78)$ & $(0.31)$ \\
\hline \multirow[t]{2}{*}{ Village has pucca road } & -0.029 & -0.048 & -0.13 & 0.092 & -0.032 & -0.113 & -0.148 & -0.018 \\
\hline & $(0.22)$ & $(0.73)$ & $(0.88)$ & $(1.16)$ & $(0.22)$ & $(1.65)^{+}$ & $(1.05)$ & $(0.26)$ \\
\hline \multirow[t]{2}{*}{ Village has electricity } & -0.113 & 0.123 & -0.236 & 0.13 & 0.01 & -0.015 & 0.114 & 0.037 \\
\hline & $(0.53)$ & $(1.34)$ & $(1.07)$ & $(1.21)$ & $(0.04)$ & $(0.16)$ & $(0.49)$ & $(0.39)$ \\
\hline \multirow[t]{2}{*}{ \# of mosques in the village } & -0.097 & -0.065 & -0.092 & 0.014 & -0.225 & -0.014 & -0.071 & -0.034 \\
\hline & $(0.65)$ & $(2.67)^{* *}$ & $(0.51)$ & $(0.48)$ & $(1.45)$ & $(0.58)$ & $(0.43)$ & $(1.36)$ \\
\hline \multirow[t]{2}{*}{ Village semi urban } & 0.05 & -0.05 & 0.144 & -0.011 & -0.291 & 0.105 & -0.216 & -0.025 \\
\hline & $(0.21)$ & $(0.46)$ & $(0.54)$ & $(0.09)$ & $(1.21)$ & $(0.99)$ & $(0.88)$ & $(0.24)$ \\
\hline \multirow[t]{2}{*}{ Village economic inequality } & -0.003 & 0.002 & 0.002 & 0.002 & 0 & 0 & -0.004 & -0.001 \\
\hline & $(1.53)$ & $(2.67)^{* *}$ & (1.04) & $(1.78)+$ & $(0.19)$ & $(0.49)$ & $(2.11)^{*}$ & $(0.84)$ \\
\hline \multirow[t]{2}{*}{ Village has NGO presence } & 0.457 & -0.017 & 0.154 & -0.043 & -0.159 & -0.022 & 0.005 & -0.085 \\
\hline & $(2.22)^{*}$ & $(0.28)$ & $(0.67)$ & $(0.56)$ & $(0.73)$ & $(0.34)$ & $(0.02)$ & (1.35) \\
\hline Observations & 452 & 1735 & 383 & 1303 & 468 & 1823 & 450 & 1725 \\
\hline Pseudo $\mathrm{R}^{2}$ & 0.08 & 0.03 & 0.07 & 0.05 & 0.14 & 0.08 & 0.17 & 0.07 \\
\hline
\end{tabular}

Note: See Table 2. 